\title{
Red Mud from the Aluminium Industry: Production, Characteristics, and Alternative Applications in Construction Materials-A Review
}

\author{
Nathália C. G. Silveira ${ }^{1, *}$, Maysa L. F. Martins ${ }^{1,2}$, Augusto C. S. Bezerra ${ }^{2,3, * \mathbb{C}}$ and Fernando G. S. Araújo ${ }^{1,4}$ \\ 1 Department of Materials Engineering, Federal University of Ouro Preto, Ouro Preto 35400-000, MG, Brazil; \\ maysa.martins@aluno.ufop.edu.br (M.L.F.M.); fgabriel@iceb.ufop.br (F.G.S.A.) \\ 2 Federal Center for Technological Education of Minas Gerais, Department of Materials Engineering, \\ Belo Horizonte 30421-169, MG, Brazil \\ 3 Federal Center for Technological Education of Minas Gerais, Department of Transports Engineering, \\ Belo Horizonte 30421-169, MG, Brazil \\ 4 Department in Engineering and Continuing Education-DEPEC of the Gorceix Foundation, \\ Ouro Preto 35400-000, MG, Brazil \\ * Correspondence: nathalia_cgs@hotmail.com (N.C.G.S.); augustobezerra@cefetmg.br (A.C.S.B.)
}

Citation: Silveira, N.C.G.; Martins, M.L.F.; Bezerra, A.C.S.; Araújo, F.G.S. Red Mud from the Aluminium Industry: Production, Characteristics, and Alternative Applications in Construction Materials-A Review. Sustainability 2021, 13, 12741.

https://doi.org/10.3390/su132212741

Academic Editor: Vincenzo Torretta

Received: 23 February 2021

Accepted: 16 March 2021

Published: 18 November 2021

Publisher's Note: MDPI stays neutral with regard to jurisdictional claims in published maps and institutional affiliations.

Copyright: (c) 2021 by the authors. Licensee MDPI, Basel, Switzerland. This article is an open access article distributed under the terms and conditions of the Creative Commons Attribution (CC BY) license (https:// creativecommons.org/licenses/by/ $4.0 /)$.

\begin{abstract}
About 120 million tons of red mud is produced worldwide each year. Due to its high basicity and potential leaching, its storage is a critical environmental problem. This material is typically stored in dams, which demands prior care of the disposal area and includes monitoring and maintenance throughout its useful life. Consequently, it is crucial to figure out an industrial solution able to consumes large volumes of this material. At this moment, there are several studies, the majority in metallurgical procedures, building materials, and in the chemical industry, discussing how to reuse red mud. This paper provides a review of the aluminium process, including metal importance, its global production, and the environmental impact due to its manufacture process. It presents a review of the potential application of red mud showing its overall generation, some relevant characterisation results collected from the literature, and its utilisation in diverse areas of engineering. The study aimed to highlight applications where red mud characteristics may be favourable.
\end{abstract}

Keywords: Bayer residue; waste management; red mud; aluminium

\section{Aluminium \\ 1.1. Introduction}

Aluminium is the most common metal and the third most abundant element present in the earth's crust. By mass, it occurs in about eight per cent of the earth's crust composition, but due to its chemical activity only exists in oxide forms [1,2]. Bauxite, a combination of hydrated aluminium oxides and other minerals, is the principal aluminium ore. The most common minerals present in bauxite are gibbsite $\left(\mathrm{Al}(\mathrm{OH})_{3}\right)$, boehmite $(\gamma-\mathrm{AlO}(\mathrm{OH}))$, diaspore $\alpha-\mathrm{AlO}(\mathrm{OH})$, and kaolinite $\left(\mathrm{Al}_{2} \mathrm{Si}_{5}(\mathrm{OH})_{4}\right)$, usually together with iron-bearing minerals like goethite $(\mathrm{FeO}(\mathrm{OH}))$ and hematite $\left(\mathrm{Fe}_{2} \mathrm{O}_{3}\right)$ and small amounts of anatase $\left(\mathrm{TiO}_{2}\right)$ [3-5]. Aluminium has a silvery-white aspect, is soft, non-magnetic, and ductile. It is extraordinary in applications where low density and corrosion resistance are essential. On the other hand, aluminium does not perform well at elevated temperatures because of its low melting temperature $[1,6]$.

This nonferrous material is produced industrially by the Bayer process followed by the Hall-Heroult procedure. The first step is a hydrometallurgical extraction and refinement of alumina from bauxite ore. It is performed at temperatures of up to $240{ }^{\circ} \mathrm{C}$ and includes digesting crushed bauxite in strong sodium hydroxide solutions, resulting in alumina and an insoluble residue (red mud). The second part (Hall-Heroult process) 
is electrolysis refinement and consists of the decomposition of alumina dissolved in an electrolyte $\left(\mathrm{Na}_{3} \mathrm{AlF}_{6}\right)$ at $950-970{ }^{\circ} \mathrm{C}$ followed by a purification stage, producing the metallic aluminium [6,7].

Applications of alumina cover some sectors; the market for bionic implants is worth around USD 25 billion in products such as pacemakers, bionic ear, bionic eye, brain stimulator, and several other bionic implants. In the semiconductor and microelectronics industries, the use of electronic alumina substrates generates around USD 50 billion. Alumina also plays a crucial role in refractory industries [8]. Aluminium-based composites are very promising structural materials due to their high resistance to corrosion and wear, in addition to having a specific module and ideal weight for automotive and aerospace applications [9].

Aluminium fabrication requires massive amounts of energy. To produce 1 ton of this metal, about $17,000 \mathrm{kWh}$ of electricity is required, which implies a reasonably elevated cost [10]. However, this material is exceptionally appropriate for recycling. According to the International Aluminium Institute, only about $5 \%$ of the energy that was spent to make it from virgin raw materials is required to remelt scrap aluminium [10,11].

Aluminium is the nonferrous metal most consumed all over the world [12]. Nevertheless, aluminium is hardly ever applied in its pure form. Alloys typically are developed combining aluminium with magnesium, manganese, copper, and silicon, enhancing up to 15 times the strength comparing to pure aluminium. Heat treatment and cold working similarly improve the strength of these materials $[10,13]$.

\subsection{Importance}

Aluminium is important in various segments of the economy, but its principal uses have been developed in six major industries. The consumption can be divided by sectors: $23 \%$ in transportation, followed by construction $(22 \%)$, packaging $(13 \%)$, electrical $(12 \%)$, machinery and equipment $(8.5 \%)$, consumer durables $(4.5 \%)$, and other segments $(4 \%)[14,15]$. It becomes the second most used metal only after steel for modern societies. These metals are versatile, economical, and attractive for a wide diversity of uses [3,14,15].

Almost three times lighter than steel, this metal is superior in fuel efficiency, becoming appropriate for automotive, defence, and aviation $[16,17]$. Aluminium alloys are used in the construction industry on several products from exterior finishing to structural components because of its aesthetical appearance, durability, and non-corrosive properties [18]. It is suitable in the electrical and electronics industries due to its ability to conduct heat and electricity [19]. Moreover, being infinitely recyclable, the packaging industry applies aluminium in their products, for example, in beverage cans and foils [20].

\subsection{Global Production}

According to the United States Geological Survey, almost sixty million tons of aluminium as a pure metal was produced in 2015 [3,21]. Figure 1 shows the overall aluminium production during the last century, starting in 1920, the year in which aluminium production became industrially relevant.

It can be seen that aluminium volume has increased about $2.5 \%$ per year for the last 25 years; 19 million tons were produced in 1990, facing 58 million manufactured in 2015. By 2020, the demand is expected to have increased to around 97 million tons. Nowadays, nearly $50 \%$ of the scrap is end-of-life products, confirming its recyclability [3,21]. The major mining is in developing countries. Primary aluminium production is becoming more energy-efficient; however, without any significant improvement in the process, that would allow the use of poorer ores. Only iron has a higher mine production than aluminium. Around 1450 million tons of iron are extracted every year [3,47]. 


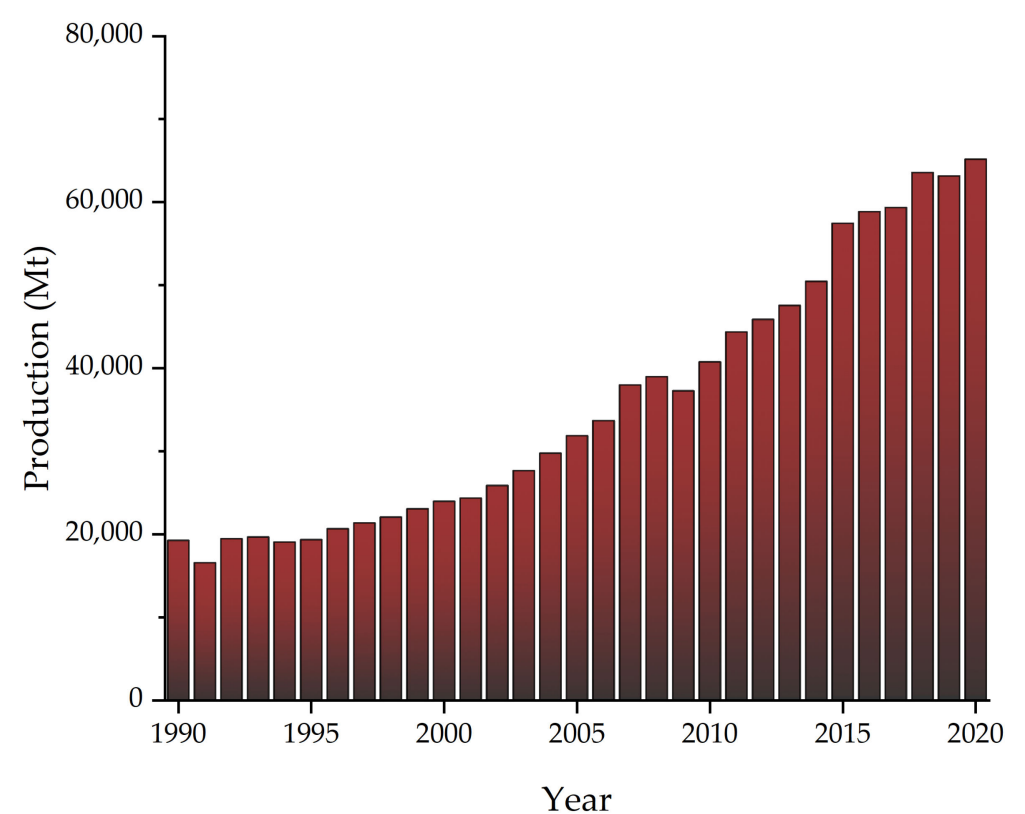

Figure 1. Worldwide aluminum production for the past thirty years [22-46].

The bauxite for the extraction of aluminium had an increase in consumption of $30 \%$ in 2019 when compared to the year 2018. Approximately 73\% of the bauxite is refined by the Bayer process, and $66 \%$ of the alumina resulting from the process is destined for the production of the aluminium primary [46]. The production of alumina can also occur by sintering the bauxite mixture and caustic soda at a temperature of $1200{ }^{\circ} \mathrm{C}$. The residue undergoes acidic treatments, usually with hydrochloric acid, to neutralise its alkalinity. Eleven countries stand out in bauxite production (Figure 2), with the largest producers being Australia, Guinea, China, and Brazil. Guinea increased its production in the last year, about $43.8 \%$, surpassing China, which reduced its production by $6 \%$. Brazil maintained its production, and Australia had a 15\% growth [46].

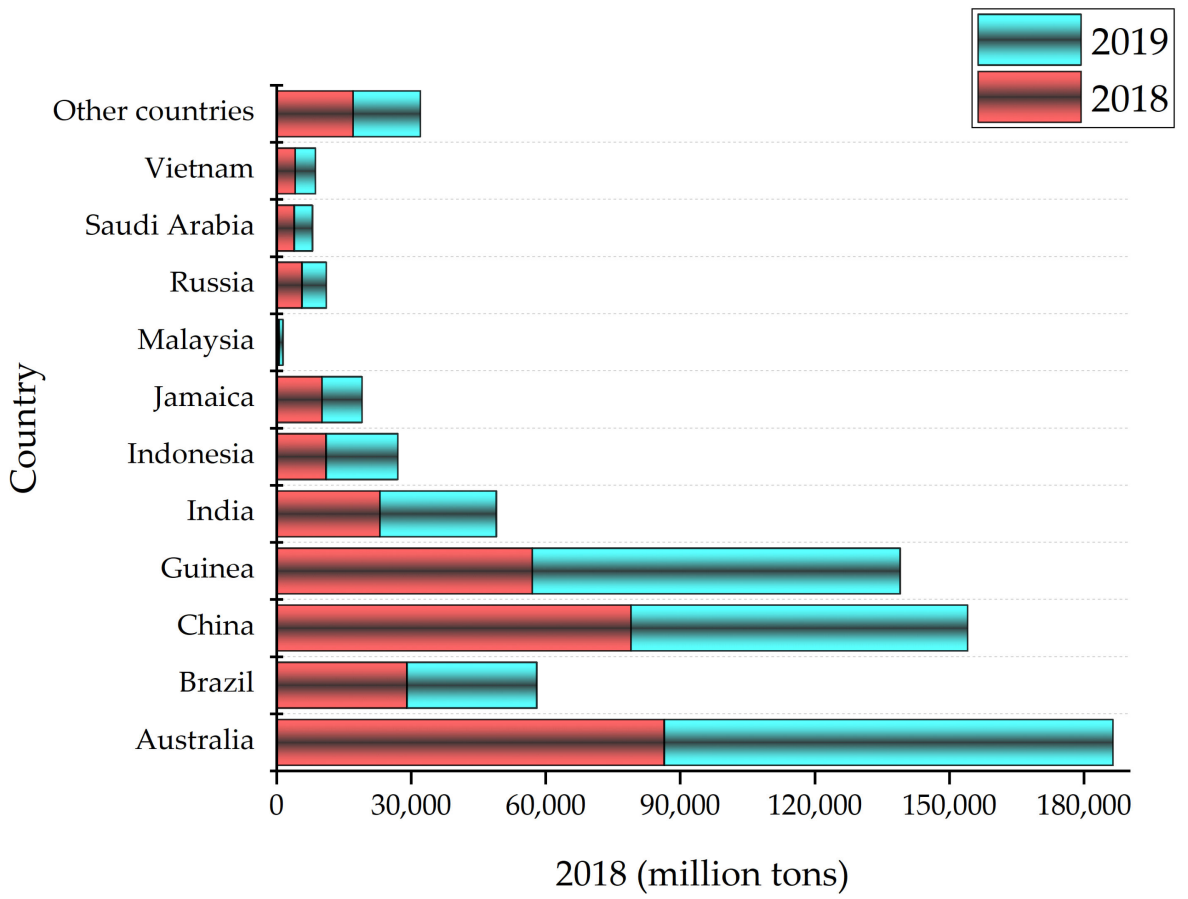

Figure 2. Bauxite mine production in 2018 and 2019 [46]. 
The largest alumina producers are not the largest aluminium producers except China and India, which stand out as alumina and aluminium producers (Figure 3). The production of alumina and aluminium has been maintained for the past two years [25,44]. The demand for aluminium tends to increase significantly concerning other metals, increasing by $215 \%$ from 2010 to 2050 [48].

(a)

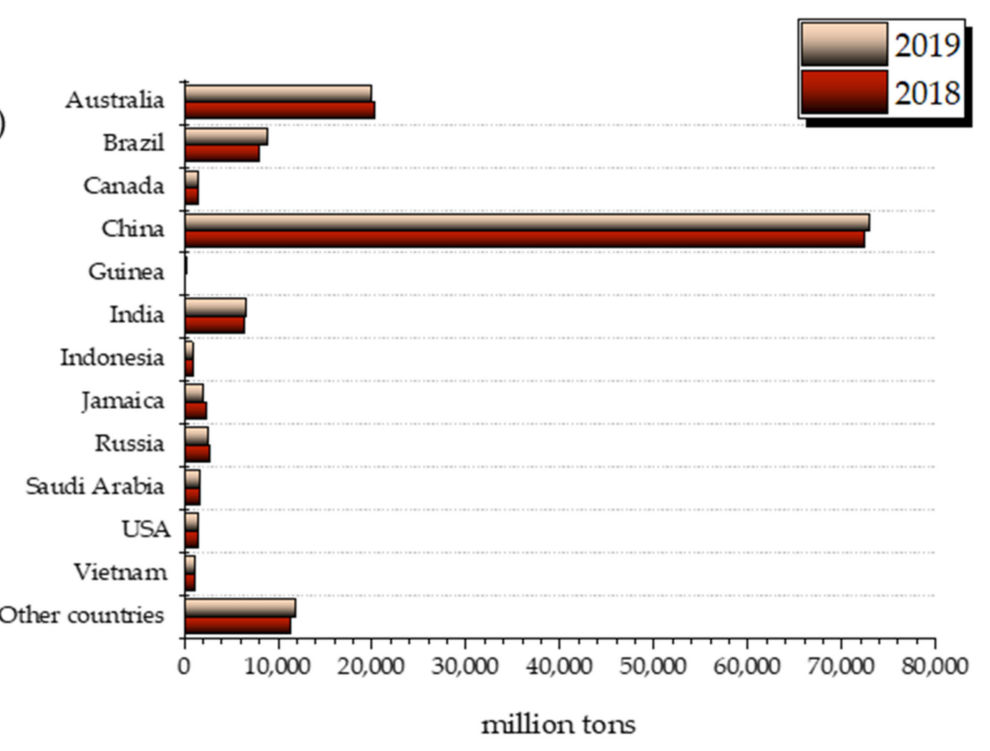

(b)

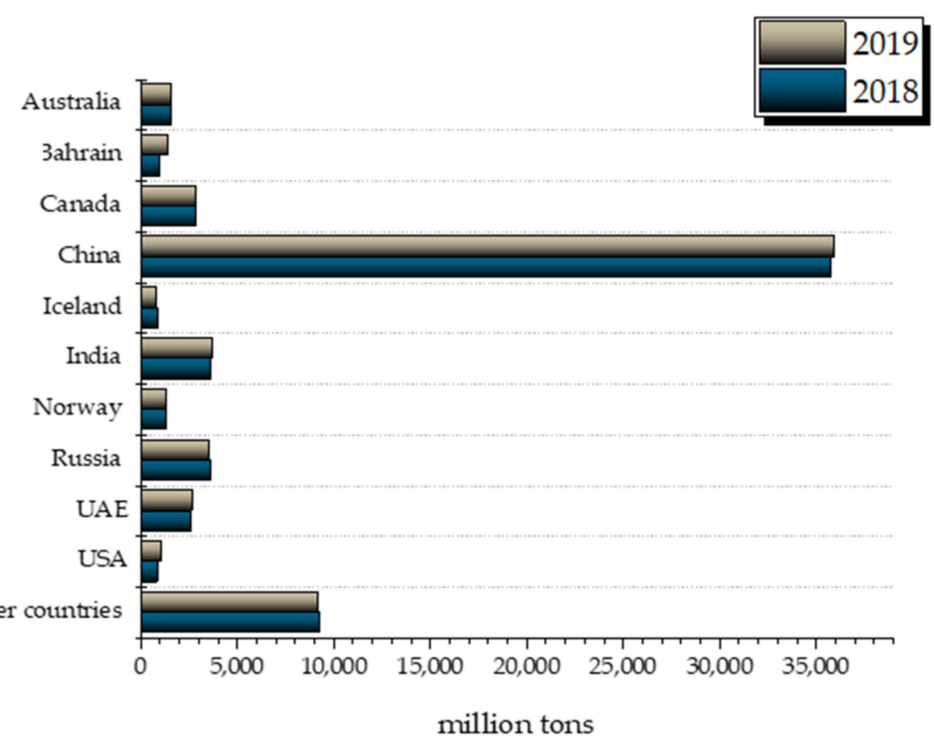

Figure 3. World smelter production: (a) alumina, (b) aluminium [45,46].

Brazil occupies the eleventh position on the primary aluminium producers ranking, preceded by China, Russia, Canada, United Arab Emirates, India, Australia, Norway, Bahrain, Saudi Arabia, and Iceland. In terms of bauxite beneficiation, Brazil is in the fourth position, behind Australia, China, and Guinea, and the third alumina producer, after China and Australia [49]. The key aluminium consumer markets include China, the United States of America, Germany, India, and Japan [15].

\subsection{Aluminium Production Impact}

All over the world, bauxite deposits often are covered by an overburden of rock and clay, which must be removed. The ore is frequently located near the surface but in small thickness, excavating relatively large land areas. About 40-50 square kilometres of land 
usually is modified (including roads and infrastructure) every year to provide aluminium. As a result, a large amount of rock rejects from the mining process is eliminated. After mining, even if the topsoil is restored, the soil loses its ability to retain water, making it unsuitable for crops. In addition, loss of biodiversity and ecosystems are associated with aluminium production $[15,50]$.

In the second stage, alumina production, red mud results from the Bayer process as a reject. It is as red sludge containing iron, titanium, and silicon oxides in the majority and aluminium oxide unsuccessfully extracted, together with sodium hydroxide. It is an extremely alkaline residue as sodium hydroxide is added during the Bayer process [51,52]. Typically, about $4-5$ tons of red mud is discarded per 1 ton of aluminium metal produces. The mud produced is usually transported to a dam, and in sequence, it can go through a dehydration and drying process to reduce its volume and maintenance costs. [53,54]. It is estimated that only in Brazil, 10.6 million tons of this material is thrown away per year, while the world generates about 117 million tons in the same period [55]. The main problem of red mud, as can be seen, is the considerable volume generated. Besides, there is a huge hazard associated with water and soil contamination due to its high alkalinity ( $\mathrm{pH}$ between 10 and 13), the occurrence of heavy metals, and even traces of radioactive elements $[51,55,56]$. Together with the need for a large storage area for disposal, permanent care is required with maintenance and monitoring. It is calculated that only Brazilian companies spend about USD 106 million annually to ensure the safe disposal of red mud [55]. Other impacts include air pollution from alumina refining, where caustic gases and other corrosive dust are released into the atmosphere. Vast amounts of water are fundamental throughout this phase of the process, although the most significant volume is reused [57-59].

Finally, producing pure aluminium is a critical phase, resulting in atmospheric emissions, more significant energy consumption, and the generation of other solid wastes. Aluminium is a very stable metal; consequently, the energy required for its production is too high, reaching up to $20-40$ per cent of the total production cost. Generally, an industrial plant where alumina turns into aluminium must use its power stations. Due to this fact, there are even more impacts on the environment depending on the power generation type, as frequently it includes fossil oil burning or often, these power stations are hydroelectric. Emissions from aluminium reduction processes include the emission of gases, vapours, and particulate materials, the main ones being carbon monoxide $(\mathrm{CO})$, carbon dioxide $\left(\mathrm{CO}_{2}\right)$, volatile organic compounds, sulphur oxides (SOx), aluminium, and calcium fluoride $\left(\mathrm{AlF}_{3}\right.$ and $\mathrm{CaF}_{2}$, respectively). In addition, there are perfluorocarbons tetrafluoromethane $\left(\mathrm{CF}_{4}\right)$ and hexafluoroethane $\left(\mathrm{C}_{2} \mathrm{~F}_{6}\right)$. Polycyclic aromatic hydrocarbons (PAHs) are some of the pollutants produced during the electrolytic process that deserves special attention, as it presents carcinogenic properties. The electrolytic cube in its end-life is as well a solid waste [15].

Because of this, there is a need for research that expands the frontier of knowledge, adding efforts with governments and producers to adopt a circular economy model [60]. The circular economy adds value to products, making it possible to reduce waste [61]. The waste transformation into products and clean energy promotes society's progress to become circular economies. In this way, it is possible to have more durable, recyclable, and renewable inputs. Studies show that the use of by-products can promote economic improvements in society due to the circularity of resources, which is a reflection of the transition from contemporary (consumerist) behaviours to more sustainable habits [62-64]. In this work, the possibility for disposal of the red sludge of the aluminium production process is presented.

\section{Red Mud}

\subsection{Global Production}

The most used and cheapest method to treat this residue is the wet one, which consists of adding water to the mud and disposing of the solution for sedimentation. However, 
this method has a high potential for environmental impact. This sludge represents an environmental and economic problem, once about 2.7 billion tons of red mud is disposed of worldwide, and growth is estimated at nearly 120 million tons per year [53,60]. The global inventory of red mud is estimated at 4 billion tons, considering its current production [65-67].

The red mud is transported to the tailing region as a sludge, i.e., with a large amount of water and low solids content. In this way, large lagoons of the residue are formed, like dams. Each tailings dam for red mud is typically used for four to seven years, but its break risk will always be present [11]. Some disasters have already happened. In 2010, around $700,000 \mathrm{~m}^{3}$ of red mud poured in Ajka, Hungary. Ten people were killed, hundreds were seriously injured, and about $40 \mathrm{~km}^{2}$ of the agricultural area was devastated $[68,69]$.

Similarly, in January 2018, another disaster occurred in Belem, Brazil. A powerful rain caused red mud storage overflows, contaminating soil and threatening drinking water by high levels of lead and aluminium [55]. The red mud also can be converted into a dry cake as pressure filters reduce its moisture content. Then, it is stored using dry mud stacking, which is less hazardous [70,71].

The amount of red mud generated depends on two factors. The first is the quality of the ore, and the second refers to the processing conditions employed. Several authors have estimated the volume of red mud generated. Reported values range from 0.3 ton for each ton of best quality bauxite processed to 2.5 ton per ton of lower quality bauxite $[11,70]$.

The principal factors include the amount of aluminium on the original bauxite, type of aluminium oxide or hydroxide present on the ore, and pressure conditions used during the manufacturing process. In addition, the nature and type of alumina, energy, and transportation costs affect the volume of waste generated [11].

As can be seen, the volume of red mud annually generated is appreciable, showing that its incorrect disposal has a high environmental impact. Thus, it is essential to find an effective recycling method since land preparation costs, dam monitoring, and maintenance costs are extensive [72]. According to Mukiza et al. (2019), red mud disposal costs represent about $2 \%$ of its total production value, i.e., approximately USD $10 /$ ton. Some sources indicate that $5 \%$ of the aluminium's production value is located in red mud management. According to the same authors, only Brazilians annually spend about USD 106 million to ensure the safe disposal of red mud [55].

\subsection{Characterisation}

For the several applications of this waste, it is essential to know the red mud characteristics to highlight their potentialities. As discussed in the previous sections, red mud is a waste resulting from the Bayer process for alumina production. Consequently, its constitution is a mixture of compounds initially present in the original ore (bauxite) and other substances generated during the Bayer cycle [73,74].

Several studies revealed that the material contains aluminium hydroxides, alumina, iron oxides, quartz, titanium dioxide, calcium, and sodium oxides and hydroxides. In addition to these, other elements can be found in smaller quantities, namely $\mathrm{Na}, \mathrm{K}, \mathrm{Cr}, \mathrm{V}, \mathrm{Ni}$, $\mathrm{Ba}, \mathrm{Cu}, \mathrm{Mn}, \mathrm{Pb}, \mathrm{Zn}$ and V, Ga, P, Mn, Mg, Zn, Th, Cr, Nb oxides [11,75]. There is a variation in chemical composition among different red muds worldwide, as their composition is strongly influenced by the mineral deposit region [76-78].

The oxides from Table 1 can organise in several minerals' forms, which also requires characterisation. Hairi et al. characterised the mineralogical composition of a red mud sample as containing hematite $\left(\mathrm{Fe}_{2} \mathrm{O}_{3}\right)$, gibbsite $\left(\gamma-\mathrm{Al}(\mathrm{OH})_{3}\right)$, boehmite $(\gamma$-AlOOH $)$, goethite $(\alpha-\mathrm{FeOOH}), \mathrm{TiO}_{2}$ in the anatase polymorph, quartz $\left(\mathrm{SiO}_{2}\right)$, and a hydrated sodium aluminosilicate $\left(1.08 \mathrm{Na}_{2} \mathrm{O} \cdot \mathrm{Al}_{2} \mathrm{O}_{3} \cdot 1 \cdot 68 \mathrm{SiO}_{2} \cdot 1 \cdot 8 \mathrm{H}_{2} \mathrm{O}\right)$ [79]. Hu et al. also detected quartz, hematite, calcite $\left(\mathrm{CaCO}_{3}\right)$, sodalite $\left(\mathrm{Na}_{8}\left(\mathrm{Al}_{6} \mathrm{Si}_{6} \mathrm{O}_{24}\right) \mathrm{Cl}_{2}\right)$, chantalite $\left(\mathrm{CaAl}_{2}\left(\mathrm{SiO}_{4}\right)(\mathrm{OH})_{4}\right)$, and gibbsite in red mud [80]. A similar Ukrainian study described red mud by the following mineralogical composition (\% by mass): $25-27 \%$ hematite, $25-28 \%$ goethite, $4.5-6.5 \%$ rutile and anatase, $15-17 \%$ hydrogarnets, 6-7\% sodium aluminosilicate hydrate, $2.5-3.0 \%$ calcite [81]. 
Bădănoiu and her team found in their study hematite, iron titanium oxide, sodium aluminium silicate, aluminium silicate hydrate, cancrinite, and calcium aluminium silicate hydrate [82]. There can also be organic compounds on the residue, as a result of vegetable and organic substances in the bauxite/overburden and modifiers or flocculants added during the process, mainly carbohydrates, alcohols, phenols, and the sodium salts of polybasic and hydroxy acids such as humic, fulvic, succinic, acetic, or oxalic acids $[78,83]$.

Red mud is extremely fine in terms of particle size distribution. According to Silva and other authors, $95 \%$ of the volume is below $44 \mu \mathrm{m}$, with specific surface area (by BrunauerEmmett-Teller (BET) analysis) values between 13 and $22 \mathrm{~m}^{2} \cdot \mathrm{g}^{-1}$ [76]. Sutar and other collaborators [77] described a distribution with $90 \%$ of the material with a particle size below 75 microns and a specific surface area between 10 and $30 \mathrm{~m}^{2} \cdot \mathrm{g}^{-1}$. Lima and his team described specific surface area values in a larger range from 20 to $30 \mathrm{~m}^{2} \cdot \mathrm{g}^{-1}$. In the same work, they characterised red mud with particles smaller than $290 \mu \mathrm{m}$ and by its average diameter between 0.4 and $0.6 \mu \mathrm{m}$. The authors highlighted the importance of particle size measurement, as this strongly affects the rheological properties and, consequently, the possible applications for this material [75]. Likewise, Rai et al. identified red mud as extremely low in size, as its average diameter is smaller than $10 \mu \mathrm{m}$. They similarly referred to the specific surface area between 14 and $25 \mathrm{~m}^{2} \cdot \mathrm{g}^{-1}$. Finally, according to this paper, red mud real density is around 3 to $3.8 \mathrm{~g} . \mathrm{cm}^{-3}$ [70]. The red mud's surface area may vary according to the type of manufacturing process and their methodologies. Shoppert et al. showed that the red mud's surface area from the Bayer process has a greater surface area than that obtained by the sintering process. However, when subjected to alkaline fusion at $300{ }^{\circ} \mathrm{C}$, the surface area can double in size [91]. The chemical characteristics, particle size distribution, and behaviour of the residue are affected by the original bauxite. In general, the coarse fraction (greater than $100 \mu \mathrm{m}$ ) is rich in quartz and can be separated from the finer silty muds (typically 80\% less than $10 \mu \mathrm{m}$ ). These coarse fractions are known as "red oxide sand" or "sand residue", and only the fine portions are named "red mud". Usually, the first fraction is destined for road construction around the residue deposition locations as a drainage layer under the mud or as a topping material, as it has superior draining behaviour and inferior caustic behaviour [78].

The red mud generated in Brazil has an average of $34 \%$ iron oxide and $5.5 \%$ titanium oxide, making it a potential source for these metals recovering. There is also the presence in low concentrations of rare earth elements, but its mineral phases are complicated to identify because they are associated with other oxides [88]. According to Shinomiya, after the extraction, $\mathrm{Fe}_{2} \mathrm{O}_{3}$ can be used in steel metallurgy and $\mathrm{TiO}_{2}$ for paints and cosmetics production, and it also has potential for application in special alloys, suitable for prosthesis manufacturing and aerospace industry [73]. Table 2 summarises some chemical compositions specific to Brazilian studies.

Ribeiro studied Brazilian red mud and found a specific surface area of $20.27 \mathrm{~m}^{2} \cdot \mathrm{g}^{-1}$, density of $2.90 \mathrm{~g} . \mathrm{cm}^{-3}$, and a $\mathrm{pH}$ of 12.95. As expected, they also described alumina and iron oxide as the predominant red mud constituents, followed by smaller amounts of $\mathrm{SiO}_{2}$ and $\mathrm{Na}_{2} \mathrm{O}$ (or $\mathrm{NaOH}$ ). As a result, the authors suggested that non-calcined red mud has the potential to be applied on mortars and concretes for non-structural applications, partially replacing the cement in the mixture [92].

Mercury and other authors estimated red mud specific surface area as $12.96 \mathrm{~m}^{2} . \mathrm{g}^{-1}$ and density of $2.65 \mathrm{~g} . \mathrm{cm}^{-3}$. X-ray diffraction analysis in this paper detected hematite, goethite, gibbsite, sodalite, anatase, calcite, nepheline, perovskite, pseudo brookite, and quartz [93]. 
Table 1. Chemical composition for red mud described in international papers.

\begin{tabular}{|c|c|c|c|c|c|c|c|c|c|c|c|c|}
\hline \multirow[b]{2}{*}{$\begin{array}{l}\text { Composition } \\
\text { (\% wt.) }\end{array}$} & \multicolumn{12}{|c|}{ Papers } \\
\hline & $\begin{array}{l}\text { Krivenko et al., } \\
\text { 2017. [81] } \\
\text { (Ukraine) }\end{array}$ & $\begin{array}{l}\text { Do et al., } \\
2019 . \\
\text { [84] (South } \\
\text { Korea) }\end{array}$ & $\begin{array}{l}\text { Hairi et al., } \\
\text { 2015. [79] } \\
\text { (Canada) }\end{array}$ & $\begin{array}{l}\text { Hu et al., } 2019 . \\
\text { [80] (China) }\end{array}$ & $\begin{array}{l}\text { Cardenia et al., } \\
\text { 2018. [85] } \\
\text { (Greece) }\end{array}$ & $\begin{array}{l}\text { Koshy et al., } \\
\text { 2019. [86] } \\
\text { (China) }\end{array}$ & $\begin{array}{l}\text { Lemougna et al., } \\
\text { 2017. [53] } \\
\text { (China) }\end{array}$ & $\begin{array}{l}\text { Pérez- } \\
\text { Villarejo et al., } \\
\text { 2012. [87] } \\
\text { (Spain) }\end{array}$ & $\begin{array}{l}\text { Borra et al., } \\
\text { 2015. [88] } \\
\text { (Greece) }\end{array}$ & $\begin{array}{l}\text { Agrawal et al., } \\
\text { 2021 [89] } \\
\text { (India) }\end{array}$ & $\begin{array}{l}\text { Valeev et al., } \\
2019 \text { [90] } \\
\text { (Russia) }\end{array}$ & $\begin{array}{l}\text { Khairul et al., } \\
\text { 2019 [51] } \\
\text { (USA) }\end{array}$ \\
\hline $\mathrm{Al}_{2} \mathrm{O}_{3}$ & 12.9 & 19.87 & 22.12 & 17.89 & 16.25 & 21.8 & 18.47 & 19.80 & 23.60 & 22.07 & 11.8 & 18.40 \\
\hline $\mathrm{SiO}_{2}$ & 4.8 & 15.12 & 10.52 & 19.43 & 6.97 & 11.0 & 9.39 & 8.77 & 10.20 & 11.81 & 8.71 & 8.50 \\
\hline $\mathrm{Na}_{2} \mathrm{O}$ & - & 14.92 & 6.82 & 12.18 & 3.83 & 8.0 & 5.11 & 5.02 & 2.50 & 10.21 & 0.27 & 6.10 \\
\hline $\mathrm{CaO}$ & 10.1 & 7.1 & 1.36 & 2.66 & 11.64 & 1.6 & 14.19 & 4.54 & 11.20 & 1.62 & 23.80 & 7.70 \\
\hline $\mathrm{TiO}_{2}$ & 5.3 & 5.24 & 7.61 & 0.72 & 4.27 & 7.0 & 5.42 & 10.09 & 5.70 & 15.6 & 3.54 & 18.40 \\
\hline $\mathrm{SO}_{3}$ & - & 0.72 & 0.59 & & - & 0.5 & & - & - & - & - & - \\
\hline $\mathrm{K}_{2} \mathrm{O}$ & - & 0.11 & 0.55 & 0.37 & - & 0.1 & 0.10 & 0.14 & - & - & - & - \\
\hline $\mathrm{Cr}_{2} \mathrm{O}_{3}$ & - & - & - & - & - & - & - & - & - & - & - & - \\
\hline $\mathrm{ZrO}_{2}$ & - & - & - & - & - & - & - & - & - & - & - & - \\
\hline $\mathrm{SO}_{2}$ & - & - & - & - & - & - & 0.33 & - & - & - & - & - \\
\hline $\mathrm{MnO}$ & - & - & 0.02 & - & - & - & 0.09 & - & - & - & - & - \\
\hline $\mathrm{P}_{2} \mathrm{O}_{5}$ & - & - & 0.21 & - & - & 0.2 & - & - & - & - & 0.95 & - \\
\hline Others & 2.5 & - & - & - & 2.04 & - & - & - & - & - & 0.42 & - \\
\hline $\begin{array}{l}\text { Loss of } \\
\text { ignition }\end{array}$ & - & 13.68 & 10.51 & 12.84 & 36.912 .66 & 8.7 & - & - & - & - & - & - \\
\hline
\end{tabular}


Table 2. Chemical composition for red mud described in Brazilian papers.

\begin{tabular}{|c|c|c|c|c|c|}
\hline \multirow[b]{2}{*}{ Composition (\% wt.) } & \multicolumn{5}{|c|}{ Papers } \\
\hline & $\begin{array}{l}\text { RIBEIRO et al., } \\
\text { 2011.[92] } \\
\text { (Minas Gerais) }\end{array}$ & $\begin{array}{c}\text { MERCURY et al., } \\
\text { 2011. [93] } \\
\text { (Maranhão) }\end{array}$ & $\begin{array}{l}\text { ROMANO et al., } \\
\text { 2019. [94] } \\
\text { (Minas Gerais) }\end{array}$ & $\begin{array}{l}\text { ALEKSEEV et al., } \\
\text { 2019. [95] } \\
\text { (São Paulo) }\end{array}$ & $\begin{array}{c}\text { MANFROI et al., } \\
\text { 2014. [96] } \\
\text { (Minas Gerais) }\end{array}$ \\
\hline $\mathrm{Fe}_{2} \mathrm{O}_{3}$ & 19.85 & 31.22 & 22.6 & 29.9 & 27.50 \\
\hline $\mathrm{Al}_{2} \mathrm{O}_{3}$ & 19.87 & 20.77 & 25.0 & 21.2 & 30.35 \\
\hline $\mathrm{SiO}_{2}$ & 14.34 & 14.37 & 20.2 & 15.5 & 1.62 \\
\hline $\mathrm{Na}_{2} \mathrm{O}$ & 7.35 & 9.87 & 8.78 & 10.3 & 10.80 \\
\hline $\mathrm{CaO}$ & 4.61 & 2.49 & 3.83 & 4.2 & 4.12 \\
\hline $\mathrm{TiO}_{2}$ & 2.66 & 4.55 & 3.37 & 2.4 & 3.98 \\
\hline $\mathrm{SO}_{3}$ & - & - & - & 0.6 & - \\
\hline $\mathrm{MgO}$ & - & 3.92 & - & - & - \\
\hline $\mathrm{K}_{2} \mathrm{O}$ & 1.87 & 0.20 & 2.26 & 0.4 & 2.84 \\
\hline $\mathrm{Cr}_{2} \mathrm{O}_{3}$ & - & - & - & - & - \\
\hline $\mathrm{ZrO}_{2}$ & - & - & - & - & 1.60 \\
\hline $\mathrm{MnO}$ & 0.21 & - & 0.42 & 0.2 & - \\
\hline $\mathrm{P}_{2} \mathrm{O}_{5}$ & - & - & - & 0.6 & - \\
\hline Loss of ignition & 27.20 & 12.61 & 14.1 & 14.4 & 13.00 \\
\hline
\end{tabular}

Romano et al. observed on their mineral characterisation sodalite because of bauxite digestion by caustic soda and the original ore minerals, hematite, quartz, goethite, calcite, anatase, and dicalcium silicate. They also found gibbsite from incomplete digestion [94]. Alekseev and his team also described the mineral composition for red mud as hematite and quartz in the majority. However, they detected magnetite in their sample. The density of red mud was also different from the other studies mentioned. They found a much smaller value: $0.86 \mathrm{~g} . \mathrm{cm}^{-3}$ [95].

Manfroi and her team detected chantalite, cancrinite, gibbsite, hematite, quartz, and calcite in the red mud. The particle size distribution showed that $100 \%$ of the particles were smaller than $18 \mu \mathrm{m}$ [96].

In conclusion, red muds are a highly complex and diverse material. Therefore, the scientific community faces enormous challenges in standardising processes to develop a red mud recycle route.

\subsection{Research}

\subsubsection{Possible Applications}

Red mud had been considered an unusable waste for the aluminium industry for an extended period. However, the economic costs and environmental risks associated with its disposal have motivated companies and researchers to look for eco-friendly alternatives to reduce the waste volume. Nevertheless, only a small percentage $(<5 \mathrm{wt} \%)$ is reused in specific countries in industrial processes, for example, on cement production. Then, all the remaining material is being stored $[53,97,98]$.

A considerable number of potential uses have been reported in the literature or already patented. According to the data evaluated by Shinomiya, only between 1964 and 2008, 734 patents were registered using red mud in their processes [69]. The most significant difficulty to be faced is the variation in its chemical composition as a function of the ore location, as well as the process employed [75].

The several kinds of research include metallurgical processes because iron oxide is present in a substantial amount $(35-60 \%)$ together with $\mathrm{TiO}_{2}(5-15 \%)$, making the red mud suitable for these materials' recovery. However, a sintering process is required to neutralise the effect of high $\mathrm{Na}_{2} \mathrm{O}$ and aluminium content. Secondary constituents, such as rare earth elements also have been recovered, for example, Sc, Y, La, Ce, Pr, Nd, Sm, $\mathrm{Eu}, \mathrm{Gd}, \mathrm{Tb}, \mathrm{Dy}, \mathrm{Ho}, \mathrm{Er}, \mathrm{Tm}, \mathrm{Yb}, \mathrm{Lu}$, etc. [76]. Geng and his group developed a method to prepare a crude alloy and a cleaned slag from co-reduction of a mixture of municipal solid waste incineration fly ash and red mud, followed by magnetic separation. According to them, the ash acted as a reductant due to its calcium content, improving the reduction of 
metal minerals and changing the melting temperature of the $\mathrm{CaO}-\mathrm{SiO}_{2}-\mathrm{Al}_{2} \mathrm{O}_{3}$ system. $\mathrm{Cd}$, $\mathrm{Pb}$, and $\mathrm{Zn}$ were removed via volatilisation. The cleaned slag produced showed inferior leaching ability than the standard and was comparable to those of ground granulated blast furnace slag, making the studied material suitable for cement production [99].

Portland cement production is among the main anthropological activities contributing to $\mathrm{CO}_{2}$ emissions [100]. Bearing in mind that the demand for housing, infrastructure, and sanitation is increasing, the main possibility of reductions in the civil construction sector is the partial replacement [101] or total replacement of Portland cement clinker [102]. Several studies with residues have been developed with a focus on application in binders[103]. The study of red mud in construction materials, in addition to giving a destination to a waste, contributes to the reduction of cement emissions.

Considering construction material based on red mud, this material has been investigated on special cement production [104-108]. Using wastes or secondary raw materials in construction is essential to face the diminution of primary raw materials and promote the circular economy [109]. This application is fundamental since it desires huge material volume. Studies suggest using calcined red mud as a pozzolanic material to produce mortars and concretes. Manfroi et al. tried to induce red mud pozzolanic properties by drying and calcining at various temperatures during calcium hydroxide consumption activity. They concluded that the calcination temperature affects pozzolanic activity. When calcined at $600{ }^{\circ} \mathrm{C}$, the pozzolanic activity was higher than when it was conducted at $900{ }^{\circ} \mathrm{C}$; however, the second specimens showed filler effect. In addition, they substituted ordinary Portland cement for up to $15 \%$ of red mud and evaluated its impact on the compressive strength, water absorption, and heavy metals leaching of mortars. Based on their results, they suggested the most suitable replacement is of up to $5 \%$ of the calcined waste at $600{ }^{\circ} \mathrm{C}$ [96].

Red mud has $10-20 \%$ of alumina and $6-7 \%$ of silica, which indicates its potential for utilisation in building materials production as bricks, aggregates, roofs, cement, and concretes. Nikbin et al. (2018) and Yao et al. (2013) studied a partial replacement cement by a mixture of red mud and coal industries' residue to produce concrete. Kumar and Kumar tested cement-free paving blocks and achieved a flexural strength of 3.2 to $4.5 \mathrm{MPa}$ and water absorption of $6 \%$ to $7 \%$ from $10 \%$ to $20 \%$ of red mud and $80 \%$ to $90 \%$ of fly ash mixtures [110-112].

According to Shinomiya, geopolymers are alternative cementitious materials, able to replace ordinary Portland cement, since their production reduces carbon dioxide emission, a critical point in cement manufacture. The chemical process is called geopolymerisation, and it takes place by alkaline activation from aluminosilicate compounds in a basic solution $[73,113]$. The geopolymerisation of red mud as a single precursor has limited performance, mainly due to aluminium's low availability. However, the use of aluminium-rich red mud or the incorporation of supplemental sources with metakaolin or fly ash have been studied to improve the strength. The addition of calcium-rich materials such as slag also has a positive impact on the strength of these materials [114-116]. Recent studies show that heat treatment effectively enhances red mud reactivity for geopolymer production, although liquid alkaline silicate solutions are still needed [117]. In work developed by Zhang and other researchers, red mud, reactive silica, fly ash, and sodium silicate were blended to provide additional silicon and sodium for the geopolymerisation process. In the range of compositions studied, red mud had a strength of 7 to $13 \mathrm{MPa}$, as did certain Portland cement types. Finally, the authors concluded that the material obtained has the potential for road [118].

Red mud has potential in chemicals as an absorbent to eliminate contaminants such as metal ions, dyes, phenols and their derivatives, inorganic anions, bacteria, and viruses from waste effluents. However, the small adsorption capacity and catalyst sintering of raw red mud remain an adverse effect. It also has been studied as a cheaper catalyst for chemical reactions such as hydrogenation, hydride chlorination, and hydrocarbon oxidation. Red mud has catalyst properties due to its more significant content of $\mathrm{Fe}_{2} \mathrm{O}_{3}$ and $\mathrm{TiO}_{2}$ and an inferior fraction of sintering agents like $\mathrm{Na}_{2} \mathrm{O}$ and $\mathrm{CaO}$. Its characteristics make it suitable 
for ceramics manufacture (tiles and pigments) and impermeable material to cover landfills or highways. Most patents consist of red mud in construction, metallurgical, pollution control industries, and catalyst and catalyst support [49,70,73,95].

$\mathrm{Li}$ and others evaluated a residue mixture as solid grouting material. They used gypsum dihydrate $\left(\mathrm{CaSO}_{4} \cdot 2 \mathrm{H}_{2} \mathrm{O}\right)$, flue gas desulfurisation gypsum, and phosphogypsum (the chemical gypsum generated during fertiliser production rich in phosphor) to produce a red mud-slag grouting material with different gypsum contents. They observed that as gypsums were added, the fluidity and the setting time of red mud-slag grouting materials decreased. In addition, different gypsums considerably enhanced compressive strength. They concluded that this would represent high-performance and low-cost grouting materials, which could be a more eco-friendly way to use those materials [116].

Another example of the application of red mud in large quantities is road construction. Mukiza and her team constructed and studied an eco-friendly road base material to be applied at heavy traffic road base and with tolerable leaching properties by switching natural materials by red mud and fly ash. The mechanical properties, hydration characteristics, and environmental friendliness performance of the produced material were analysed. Based on the test results, the samples which had the most considerable amount of red mud and fly ash presented the best results under mechanical tests, durability in water, and leaching examination. This group was also proven economically feasible for the reason it consumes a large portion of those wastes and reduces its disposal costs but also because it substitutes a considerable quantity of expensive natural materials.

In summary, they approved red mud and fly ash uses in road base construction [55]. Based on orthogonal experiments by Zhao and his team, red mud-based mixtures were analysed as unburned road brick. They found an optimal proportion of $35 \%$ red mud, $14 \%$ fly ash, $8 \%$ lime, $15 \%$ cement, and $28 \%$ sand. After 28 -day standard curing, the compressive strength was higher than $19 \mathrm{MPa}$ [119].

Shinomiya evaluates on his studies the most viable scenarios for red mud in Brazil, considering as relevant criteria the industries for waste processing availability, use in large quantities, and pre-treatment needs. In this paper, the author concluded that the most suitable applications for the Brazilian market are road construction, cement, and ceramic materials production [73]. Various applications described in this paper can be technically impressive but unable to utilise significant amounts of red mud. Applications such as rare earth metals recovery may be theoretically attractive but have no impact on reducing the large volumes of red mud created by alumina manufacturing unless iron, titanium, and silicon dioxide recovery were performed together to the aluminium production. Frequently, a reasonably elevated temperature is essential in applications for building materials, pollution control, and metal recovery [11]. The volume of red mud consumed by some potential applications is tiny due to high cost, complicated process, and inherent risk. As a result, this material remains in storage, and the problem is still unsolved [120]. Currently, only 3-8\% of the red mud produced is consumed by all these applications mentioned [121].

\subsubsection{Red Mud Alkalinity as Construction Material}

As can be seen, all these possible applications are considered technically successful by the literature, but there are some barriers that inhibit the massive application of the red mud by the industries. The biggest of them is the fact that in almost all situations in which red mud presents itself as a substitute, the original material is very available and cheap, and thus any negative characteristics become an obstacle [122].

Analysing the characterisation section, it can be noted that red mud is a complex material, which has priceless components and problematic utilisation. Iron, aluminium, and sodium are the principal components, which makes them easier to be recovered. However, almost $20 \%$ of $\mathrm{SiO}_{2}$ is also found, making it harder to extract those elements from the red mud. Red mud is also critical by its strong alkalinity, large specific surface area, and the ability to wrap various components [123]. 
The major adverse red mud characteristic is its high alkalinity. According to Evans, it represents a risk considering the health and safety aspect, and it is potentially adverse in the specific application. For example, a reduced weathering resistance in construction materials can be achieved or a great sodium content when used in soil amelioration. A pre-treatment of accelerating carbonation or acid neutralisation can reduce the $\mathrm{pH}$ [122]. However, the best option is converting the critical alkalinity as a favourable aspect, eliminating any additional treatment. Red mud alkalinity has been investigated in cement clinkers, production of composite cement, and alkali-activated materials as discussed below. Nevertheless, its water content remains challenging for the cement manufacturing process [124].

According to Liu and Zhang, as red mud is predominantly composed of $\mathrm{Fe}_{2} \mathrm{O}_{3}$ and $\mathrm{Al}_{2} \mathrm{O}_{3}$ - also silica - it is appropriate as a raw material for the preparation of cement clinkers [125]. Singh and his group were pioneers in this approach. They evaluated the probability of manufacturing calcium sulfoaluminoferrite $\left(\mathrm{C}_{4}(\mathrm{~A}, \mathrm{~F})_{3} \mathrm{~S}\right)$ and calcium aluminoferrite $\left(\mathrm{C}_{4} \mathrm{AF}\right)$ combining lime, red mud, bauxite, and gypsum. They observed that composition and firing temperature affect strongly cement properties. However, the firing time did not influence the same intensity. They concluded that it is feasible to produce cement with sufficient strength using the materials tested [126]. Tsakiridis and his team evaluated this probability of adding red mud as a raw meal for the Portland cement clinker production. They concluded that red mud did not change the mineralogical characteristics and did not influence the final quality, suggesting that their dosages are suitable for Portland cement clinker [127]. Wang and his team investigated desulfurised gypsum and red mud mixtures to produce sulfoaluminate cement. They found as major mineral phases $3 \mathrm{CaO} \cdot 3 \mathrm{Al}_{2} \mathrm{O}_{3}, \mathrm{CaSO}_{4}, \beta-2 \mathrm{CaO} \cdot \mathrm{SiO}_{2}$, and $2 \mathrm{CaO} \cdot \mathrm{Fe}_{2} \mathrm{O}_{3}$, typical to Portland cement. The clinkers tested exhibited exceptional strength performances. Then, they concluded that it was a suitable way to consume those industrial solid wastes, as the sulfoaluminate cement products are cheaper than Portland cement due to their low material costs, smaller pre-treatment costs, and reduced calcination temperature [128]. Likewise, Cambek and other authors concluded in their study that a mixture of red mud, a sulfate-rich/high-lime fly ash, and desulfogypsum is possible as raw materials in clinkers because the cement produced showed better mechanical performances than the reference sample [129]. Wang and his team highlighted that sometimes alkalinity avoids the large-scale utilisation of red mud in cement production. However, calcification-carbonisation red mud is efficient to produce a suitable cement clinker, as their chemical composition is similar $[130,131]$.

Some papers found that the Portland cement hydration is encouraged by a highly alkaline environment in which red mud is distinguished for [132]. Dow and Glasser demonstrated that the $\mathrm{SiO}_{2}$ and $\mathrm{Al}_{2} \mathrm{O}_{3}$ red mud contents are essential to enhance its cementitious activity [133]. Romano and this group tested partial substitution of Portland cement for different red mud contents, monitoring the hydration reaction. After their analysis, they observed that red mud changed cement hydration due to nucleation effects, packing, and dilution. The higher amount of sodium and soluble aluminates promoted sodium silicoaluminate hydrate (NASH) formation and a more significant amount of hydrated calcium aluminate, without affecting the setting time [134].

Similarly, Dodoo-Arhin and other authors replaced Portland cement with red mud up to $25 \%$ for pavement construction applications. They observed that as red mud content increases, the compressive and flexural strength decreases, but $5 \%$ of red mud addition tend to have better performance. Workability tends to decrease, and the initial and final setting reduces as aluminium and sodium hydroxides act as curing substances [124,135]. Wang and his team used red mud, limestone, and sandstone to prepare a Portland cement for road. They found the following mineral phases of the clinker produced: $C_{3} S, C_{2} S$, and $\mathrm{C}_{4} \mathrm{AF}$. When compared to ordinary Portland cement, the new materials showed smaller early compressive strength. In this study, the red mud was previously de-alkalised. They observed that an amount of over $26 \%$ harmed Portland cement minerals formation [136]. 
According to Tang and other authors, red mud can be a suitable binder material in cement matrices due to its amorphous aluminosilicate content, promoting pozzolanic reaction during the cement hydration process [137]. Liu and his group studied the impacts of red mud on magnesium phosphate cement properties (MPC). Their results revealed an increase in fluidity by adding up to $20 \%$ red mud. They also observed a decline in reaction intensity of the fresh mortar as the setting time became longer. The best mixture under the compression test was the $20 \%$ red mud, with $90.2 \mathrm{MPa}$ at 28 days. This behaviour could be explained as red mud additions reduced the final porosity. Based on these results, the authors concluded that red mud is efficient as a modifier for this specific cement [138]. Bayat and his team evaluated red mud and slag as alkali-activated slag for jointed plain concrete pavement (JPCP) production, replacing slag for red mud at levels of $10 \%, 20 \%$, $30 \%$, and $40 \%$ by weight. They noted a decrease in mechanical strength as red mud content increased. Samples with 30\% of red mud showed the best thermal properties but smaller dimensional stability [139]. Li and his team prepared red mud-yellow phosphorous slagcement concrete mixtures with $25 \%$ yellow phosphorus slag content (YPSC) and $10 \%$ red mud content (RMC) as a replacement to the cement. They concluded that this amount achieves mechanical property requirements [140]. Raj and other authors investigated an ordinary Portland cement-metakaolin-red mud blended cement, replacing from $0 \%$ to $14 \%$ of the cement mass by metakaolin and red mud in different ratios. According to them, the mixtures' consistency was proportional to the quantity of replaced due to smaller particles in red mud. They found the greatest strength in the mixture containing the ratio of 80:20 metakaolin:red mud because the first material performed as pozzolanic and the second as a filler [141]. Ghalehnov and his team analysed a mixture of red mud (RM), granite (GP), and marble (MP) as self-compacting concrete, using red mud percentages of $2.5 \%, 5 \%, 7.5 \%$, and $10 \%$ as partial replacement of cement. They observed a negative effect on the fresh properties, but a small amount of red mud together with granite and marble improved the mechanical properties. The samples with $2.5 \%$ of RM and $100 \%$ of GP showed $19 \%$ strength increases compared to the control mix [142]. Ghalenhnov, in another study, used red mud to produce a coloured concrete production. For that purpose, seven concrete mixes were tested. As a significant conclusion, they observed an improvement in resistance to sulphate attack [143].

According to Dodoo-Arhin and his team, the red mud alkalinity can be an advantage in inhibiting corrosion in reinforced concrete and reducing sulphur accumulation inside the cement kiln system [135]. When used in mortars and concrete, red mud chemical constituents promote a steel passivity film on the reinforcement bar, avoiding the corrosion process $[144,145]$. Ribeiro and his team studied the effects of red mud additions on the reinforced concrete corrosion process. They produced concrete containing different red mud levels $(10 \%, 20 \%$, and $30 \%$ to the cement mass). Electrochemical measurements monitored the corrosion potential. In summary, they observed that the high $\mathrm{pH}$ of the red mud provides greater protection to the concrete, due to its ability to enhance electrical resistivity. According to their results, red mud is a favourable addition to reinforced concrete, in order to inhibit the corrosive process [54].

Yuan and his team evaluated the red mud possibility as an alkali source in alkaliactivated fly ash and Portland cement (PC) to produce controlled low-strength material (CLSM). They noticed that as the red mud amount increases, $\mathrm{NaOH}$ from this waste dissolves the pores, and the $\mathrm{Na}_{2} \mathrm{CO}_{3}$ reacts with portlandite from cement hydration. As a result, they observed a micro-filler property because red mud content reduced the pore structure, which enhanced the strength development of CLSM [146]. Similarly, Do and Kim analysed red mud as a partial replacement for Portland cement in CLSM production. Their mixtures had ponded ash, Portland cement, Class F fly ash, water, and in some samples, Portland cement was replaced by red mud in $5 \%, 10 \%, 15 \%, 20 \%, 25 \%$, and $30 \%$ by weight. They noticed that flowability decreased as red mud content raised due to a much bigger specific surface area of red mud compared to Portland cement. In addition, the replacement of red mud accelerated the setting process of CLSM because $\mathrm{Al}_{2} \mathrm{O}_{3}$ and $\mathrm{Na}_{2} \mathrm{O}$ performed as 
a highly alkaline solution improving hydration. Then, these authors suggested that partial replacement from Portland cement to red mud in CLSM production is practical [147].

According to Ke and his team, the main technical barrier in the alkali activation process is to achieve the initial dissolution of aluminosilicate precursors. The use of precursors that already contain alkalis, which is leached out when adding water, is one solution. In this context, red mud is pointed out, bringing alkalinity suitable for geopolymerisation [148]. $\mathrm{Li}$ and his research group used municipal solid waste incineration ash and red mud to prepare geopolymeric materials. The ideal amount of ash found was $30 \%$, resulting in $12.75 \mathrm{MPa}$ at 28 days of curing at room temperature [149]. The red mud geopolymerisation as a unique precursor has limited performance due to its low availability of aluminium. However, it is possible to incorporate additional aluminium sources, like metakaolin or fly ash. The inclusion of calcium-rich materials such as slag also positively impacts the compressive strength of the red mud-based geopolymers. Recent studies showed that heat treatment of red mud and $\mathrm{NaOH}$ pellets at $800{ }^{\circ} \mathrm{C}$ is an effective way to enhance reactiveness [117]. Yang and his team evaluated a geopolymer synthesis method from red mud in its slurry state and fly ash powder. The samples were cured at $50^{\circ} \mathrm{C}$ for seven days and exhibited compressive strengths over $17 \mathrm{MPa}$ after 14 days [150]. Kumar and Kumar developed paving blocks using red mud and fly ash via geopolymerisation. To do so, they produced a fly ash geopolymer with $0 \%$ to $40 \%$ of red mud. They observed an increase of reaction intensity for all additions, but only the samples containing $5 \%$ to $20 \%$ red mud had better setting time and strength. According to them, the $\mathrm{NaOH}$ concentration, solubility of silicates, and the presence of iron oxides produced a compact microstructure, resulting in better properties [112]. Jung-Hyeok produced pavement using alkali-activated cement from red mud. They found compressive strengths higher than $15 \mathrm{MPa}$ for all samples, suggesting their application on walking and bike lanes [151]. Zhang and his team found that the best molar ratios of $\mathrm{Na} / \mathrm{Al}$ and $\mathrm{Si} / \mathrm{Al}$ are between $0.6-0.8$ and 2.0, respectively, for geopolymerisation reactions between red mud activated and fly ash [152].

Red mud has been a source of alkali in geopolymer systems combined with fly ash. Zhang et al. produced red mud and fly ash-based geopolymers at room temperature with good mechanical properties [153]. Choo and his team verified that it is possible to replace $\mathrm{NaOH}$ with red mud as an activator, but the compressive strengths obtained for those samples were considered low ( $<4 \mathrm{MPa}, 28$ days). According to them, this occurred due to the high unburned carbon content on the fly ash used (ignition loss $>6 \%$ ) [154]. A geopolymer was synthesised from red mud combined with granulated blast furnace slag by Ye and others. Heat treatment was applied to improve geopolymerisation reactions. They found the best treatment condition was approximately $800^{\circ} \mathrm{C}$ for $3 \mathrm{~h}$, as under this situation, the material reached the highest value of $49.2 \mathrm{MPa}$ [155]. Bădănoiu and other authors tested the possibility of an alkaline activation process using waste glass (bottle glass cullet) and red mud with $\mathrm{NaOH}$ solution and thermal treatment at $60{ }^{\circ} \mathrm{C}$. They observed a negative influence of red mud addition. According to them, an insufficient amount of supplementary aluminium and a high amount of iron phases from red mud disrupted the chemical reactions, even if the alkalinity was reached [82]. Kaya and SoyerUzun produced red mud-metakaolin-based geopolymers with different red mud contents, evaluating their performance as the alkali activator. The more significant compressive strength was $51.5 \mathrm{MPa}$, and they concluded that red mud incorporation tends to harm mechanical properties. According to them, iron species from red mud are the principal factors controlling mechanical performance [156].

In summary, many of the applications described here, while technically interesting and clearly viable, are unable to use significant amounts of red mud. The current need is safe disposal and its massive use. Applications such as the recovery of the minor elements in the mud can be economically attractive but have no impact on reducing large volumes discarded [11]. Besides that, in almost all of the aforementioned applications of red mud in building materials, pollution control, and metal recovery, a reasonably high temperature is required [77]. 
The Brazilian study carried out by Shinomiya assessed the most viable scenarios for red mud, considering as relevant criteria the availability of industries for processing tailings, use in large quantities, and the need for pre-treatment of the waste. Red mud production only in Brazil is estimated to be between 7 to 10 million tonnes/year [93]. In this work, the author concluded that the most suitable applications for the Brazilian market involve the red mud use on the construction of roads, cement, and ceramic materials [73].

Reviewing the literature reveals that red mud applications are still not fully comprehended. There are many combinations between red mud and other wastes to produce a potential industrial application, which could be evaluated. Parameters like pre-treatment, amount of red mud used, and the routeing process need to be intensively studied to achieve a circular economy.

\section{Conclusions}

Despite the technological advances in recent years, the disposal of red mud is still a big problem for the aluminium industry as critical issues affect its recycling feasibility and economics. In addition, the sodium species remaining, the particle size, and the moisture content are characteristics hard to handle. Disposal and management of rejects still represent a large portion of the alumina production costs.

As mentioned, Brazil is a more significant contributor to red mud generation. Considering the volume generated, more than one application would have to be implemented to avoid its accumulation. Then, products for civil construction, in general, are great alternatives. In this paper, some possibilities were presented, including blocks for paving, material for roads and concrete, and supplementary additive for Portland cement. This concept in the valorisation of industrial waste, where waste constitutes a significant fraction, means that the processing parameters must be helped so that the final products meet the usage requirements. It is fundamental for Brazil, one of the largest red mud generators in the world, to enhance its practices.

The performance of red mud in any application must be competitive with alternatives about quality, cost, and risk. The aluminium industry should join their effort with other companies or research institutes to extend its already widespread implementation of the circular economy to the red mud critical problem.

Author Contributions: N.C.G.S.: Conceptualization, investigation, original draft preparation, data curation, writing, review, and editing. M.L.F.M.: Investigation, data curation, writing, validation, review, and formal analysis. A.C.S.B.: Conceptualization, methodology, investigation, formal analysis, review, project administration, funding acquisition, and supervision. F.G.S.A.: Methodology, original draft preparation, review, project administration, funding acquisition and supervision. All authors have read and agreed to the published version of the manuscript.

Funding: This research was funded by the Brazilian Federal Agency for the Support and Evaluation of Graduate Education (CAPES-code 001) and by Gorceix Foundation.

Institutional Review Board Statement: Not applicable.

Informed Consent Statement: Not applicable.

Conflicts of Interest: The authors declare no conflict of interest.

\section{References}

1. Altenpohl, D.G. Present Structure and Future Trends in Key Materials Industries. In Materials in World Perspective; Springer: Berlin, Germany, 1980; pp. 21-126.

2. Askeland, D.R. Polymers. In The Science and Engineering of Materials; Springer: Boston, MA, USA, 1996; pp. $488-548$.

3. Sverdrup, H.U.; Ragnarsdottir, K.V.; Koca, D. Aluminium for the future: Modelling the global production, market supply, demand, price and long term development of the global reserves. Resour. Conserv. Recycl. 2015, 103, 139-154. [CrossRef]

4. Mondillo, N.; Herrington, R.; Boni, M. Bauxites. Encycl. Geol. 2021, 694-707. [CrossRef]

5. Ruys, A. Bauxite: The principal aluminum ore. In Alumina Ceramics; Elsevier BV: Amsterdam, The Netherlands, $2019 ;$ pp. 39-47.

6. Polmear, I.; StJohn, D.; Nie, J.-F.; Qian, M. The Light Metals. In Light Alloys; Elsevier: Amsterdam, The Netherlands, 2017; pp. 1-29. 
7. Kabezya, K.; Hara, T.; Paton, R. A review of primary aluminium tapping models. SN Appl. Sci. 2019, 1, 1-9. [CrossRef]

8. Ruys, A. Introduction to Alumina Ceramics; Elsevier: Amsterdam, The Netherlands, 2019; pp. 1-37.

9. Samal, P.; Vundavilli, P.R.; Meher, A.; Mahapatra, M.M. Recent progress in aluminum metal matrix composites: A review on processing, mechanical and wear properties. J. Manuf. Process. 2020, 59, 131-152. [CrossRef]

10. Claisse, P.A. Alloys and nonferrous metals. In Civil Engineering Materials; Elsevier BV: Amsterdam, The Netherlands, 2016; pp. 361-368.

11. International Aluminium Institute. Bauxite Residue Management: Best Practice, World Alum. 2015, Volume 31. Available online: www.world-aluminium.org (accessed on 27 May 2020).

12. Zhang, Y.; Sun, M.; Hong, J.; Han, X.; He, J.; Shi, W.; Li, X. Environmental footprint of aluminum production in China. J. Clean. Prod. 2016, 133, 1242-1251. [CrossRef]

13. Ashkenazi, D. How aluminum changed the world: A metallurgical revolution through technological and cultural perspectives. Technol. Forecast. Soc. Chang. 2019, 143, 101-113. [CrossRef]

14. Guo, Y.; Zhu, W.; Yang, Y.; Cheng, H. Carbon reduction potential based on life cycle assessment of China's aluminium industry-a perspective at the province level. J. Clean. Prod. 2019, 239, 118004. [CrossRef]

15. Jawaharlal Nehru Aluminium Research Development and Design Centre Resource Efficiency Strategy for Aluminium Sector. Available online: https: / / www.google.com.hk/url?sa=t\&rct=j\&q=\&esrc=s\&source=web\&cd=\&cad=rja\&uact=8\&ved= 2ahUKEwjGr7u54Jz0AhWZ62EKHZLjAGAQFnoECBwQAQ\&url=https\%3A\%2F\%2Fwww.eu-rei.com \%2Fuserfiles\%2F050 9_NITI\%2520Session_03_Resource\%2520efficiency\%2520in\%2520Aluminium\%2520industry\%2520MoM\%25205.8.2018.pdf\& usg=AOvVaw0q72p2SzVxDrxrABMpsJoA (accessed on 27 May 2020).

16. Aamir, M.; Giasin, K.; Tolouei-Rad, M.; Vafadar, A. A review: Drilling performance and hole quality of aluminium alloys for aerospace applications. J. Mater. Res. Technol. 2020, 9, 12484-12500. [CrossRef]

17. Hirsch, J. Recent development in aluminium for automotive applications. Trans. Nonferrous Met. Soc. China 2014, 24, 1995-2002. [CrossRef]

18. Garg, P.; Jamwal, A.; Kumar, D.; Sadasivuni, K.K.; Hussain, C.M.; Gupta, P. Advance research progresses in aluminium ma-trixcomposites: Manufacturing \& applications. J. Mater. Res. Technol. 2019, 8, 4924-4939.

19. Vijayakumar, M.D.; Dhinakaran, V.; Sathish, T.; Muthu, G.; BupathiRam, P.M. Experimental study of chemical composition of aluminium alloys. Mater. Today Proc. 2020, 37, 1790-1793. [CrossRef]

20. Trowell, K.; Goroshin, S.; Frost, D.; Bergthorson, J. Aluminum and its role as a recyclable, sustainable carrier of renewable energy. Appl. Energy 2020, 275, 115112. [CrossRef]

21. Barry, J.J.; Matos, G.R.; Menzie, W.D. U.S. mineral dependence-Statistical compilation of U.S. and world mineral production, consumption, and trade, 1990-2010. Open-File Rep. 2013. [CrossRef]

22. U.S. Geological Survey Mineral Commodity Summaries 1994. Available online: https://s3-us-west-2.amazonaws.com/prdwret/assets/palladium/production/mineral-pubs/aluminum/050494.pdf (accessed on 27 May 2020).

23. U.S. Geological Survey Mineral Commodity Summaries 1997. Available online: https://s3-us-west-2.amazonaws.com/prdwret/assets/palladium/production/mineral-pubs/aluminum/050397.pdf (accessed on 27 May 2020).

24. U.S. Geological Survey Mineral Commodity Summaries 1998. Available online: https://s3-us-west-2.amazonaws.com/prdwret/assets/palladium/production/mineral-pubs/aluminum/050398.pdf (accessed on 27 May 2020).

25. U.S. Geological Survey Mineral Commodity Summaries 1999. Available online: https://s3-us-west-2.amazonaws.com/prdwret/assets/palladium/production/mineral-pubs/aluminum/050399.pdf (accessed on 27 May 2020).

26. U.S. Geological Survey Mineral Commodity Summaries 2000. Available online: https://s3-us-west-2.amazonaws.com/prdwret/assets/palladium/production/mineral-pubs/aluminum/050300.pdf (accessed on 27 May 2020).

27. U.S. Geological Survey Mineral Commodity Summaries 2001. Available online: https://s3-us-west-2.amazonaws.com/prdwret/assets/palladium/production/mineral-pubs/aluminum/050301.pdf (accessed on 27 May 2020).

28. U.S. Geological Survey Mineral Commodity Summaries 2002. Available online: https://s3-us-west-2.amazonaws.com/prdwret/assets/palladium/production/mineral-pubs/aluminum/050302.pdf (accessed on 27 May 2020).

29. U.S. Geological Survey Mineral Commodity Summaries 2003. Available online: https://s3-us-west-2.amazonaws.com/prdwret/assets/palladium/production/mineral-pubs/aluminum/050303.pdf (accessed on 27 May 2020).

30. U.S. Geological Survey Mineral Commodity Summaries 2004. Available online: https://s3-us-west-2.amazonaws.com/prdwret/assets/palladium/production/mineral-pubs/aluminum/alumimcs04.pdf (accessed on 27 May 2020).

31. U.S. Geological Survey Mineral Commodity Summaries 2005. Available online: https://s3-us-west-2.amazonaws.com/prdwret/assets/palladium/production/mineral-pubs/aluminum/alumimcs05.pdf (accessed on 27 May 2020).

32. U.S. Geological Survey Mineral Commodity Summaries 2006. Available online: https://s3-us-west-2.amazonaws.com/prdwret/assets/palladium/production/mineral-pubs/aluminum/alumimcs06.pdf (accessed on 27 May 2020).

33. U.S. Geological Survey Mineral Commodity Summaries 2007. Available online: https://s3-us-west-2.amazonaws.com/prdwret/assets/palladium/production/mineral-pubs/aluminum/alumimcs07.pdf (accessed on 27 May 2020).

34. U.S. Geological Survey Mineral Commodity Summaries 2008. Available online: https://s3-us-west-2.amazonaws.com/prdwret/assets/palladium/production/mineral-pubs/aluminum/mcs-2008-alumi.pdf (accessed on 27 May 2020).

35. U.S. Geological Survey Mineral Commodity Summaries 2009. Available online: https://s3-us-west-2.amazonaws.com/prdwret/assets/palladium/production/mineral-pubs/aluminum/mcs-2009-alumi.pdf (accessed on 27 May 2020). 
36. U.S. Geological Survey Mineral Commodity Summaries 2010. Available online: https://s3-us-west-2.amazonaws.com/prdwret/assets/palladium/production/mineral-pubs/aluminum/mcs-2010-alumi.pdf (accessed on 27 May 2020).

37. U.S. Geological Survey Mineral Commodity Summaries 2011. Available online: https://s3-us-west-2.amazonaws.com/prdwret/assets/palladium/production/mineral-pubs/aluminum/mcs-2011-alumi.pdf (accessed on 27 May 2020).

38. U.S. Geological Survey Mineral Commodity Summaries 2012. Available online: https://s3-us-west-2.amazonaws.com/prdwret/assets/palladium/production/mineral-pubs/aluminum/mcs-2012-alumi.pdf (accessed on 27 May 2020).

39. U.S. Geological Survey Mineral Commodity Summaries 2013. Available online: https://s3-us-west-2.amazonaws.com/prdwret/assets/palladium/production/mineral-pubs/aluminum/mcs-2013-alumi.pdf (accessed on 27 May 2020).

40. U.S. Geological Survey Mineral Commodity Summaries 2014. Available online: https://s3-us-west-2.amazonaws.com/prdwret/assets/palladium/production/mineral-pubs/aluminum/mcs-2014-alumi.pdf (accessed on 27 May 2020).

41. U.S. Geological Survey Mineral Commodity Summaries 2015. Available online: https://s3-us-west-2.amazonaws.com/prdwret/assets/palladium/production/mineral-pubs/aluminum/mcs-2015-alumi.pdf (accessed on 27 May 2020).

42. U.S. Geological Survey Mineral Commodity Summaries 2016. Available online: https://s3-us-west-2.amazonaws.com/prdwret/assets/palladium/production/mineral-pubs/aluminum/mcs-2016-alumi.pdf (accessed on 27 May 2020).

43. U.S. Geological Survey Mineral Commodity Summaries 2017. Available online: https://s3-us-west-2.amazonaws.com/prdwret/assets/palladium/production/mineral-pubs/aluminum/mcs-2017-alumi.pdf (accessed on 27 May 2020).

44. U.S. Geological Survey Mineral Commodity Summaries 2018. Available online: https://s3-us-west-2.amazonaws.com/prdwret/assets/palladium/production/mineral-pubs/aluminum/mcs-2018-alumi.pdf (accessed on 27 May 2020).

45. U.S. Geological Survey Mineral Commodity Summaries 2021. Available online: https://pubs.usgs.gov/periodicals/mcs2021/ mcs2021-aluminum.pdf (accessed on 27 May 2020).

46. U.S. Geological Survey Mineral Commodity Summaries 2020. Available online: https://pubs.usgs.gov/periodicals/mcs2020/ mcs2020-bauxite-alumina.pdf (accessed on 27 May 2020).

47. Dushyantha, N.; Batapola, N.; Ilankoon, I.M.S.K.; Rohitha, S.; Premasiri, R.; Abeysinghe, B.; Ratnayake, N.; Dissanayake, K. The story of rare earth elements (REEs): Occurrences, global distribution, genesis, geology, mineralogy and global production. Ore Geol. Rev. 2020, 122, 103521. [CrossRef]

48. Watari, T.; Nansai, K.; Nakajima, K. Major metals demand, supply, and environmental impacts to 2100: A critical review. Resour. Conserv. Recycl. 2021, 164, 105107. [CrossRef]

49. ABAL, A.B. de A. Bauxita no Brasil Mineração Responsável e Competitividade; São Paulo—SP, 2017. Available online: https: / / abal.org.br/publicacao/bauxita-no-brasil-mineracao-responsavel-e-competitividade/ (accessed on 27 May 2020).

50. Farjana, S.H.; Huda, N.; Mahmud, M.A.P. Impacts of aluminum production: A cradle to gate investigation using life-cycle assessment. Sci. Total Environ. 2019, 663, 958-970. [CrossRef]

51. Khairul, M.; Zanganeh, J.; Moghtaderi, B. The composition, recycling and utilisation of Bayer red mud. Resour. Conserv. Recycl. 2019, 141, 483-498. [CrossRef]

52. Tabereaux, A.T.; Peterson, R.D. Aluminum Production. In Treatise on Process Metallurgy; Elsevier Ltd.: Amsterdam, The Netherland, 2014; Volume 3, pp. 839-917. ISBN 9780080969886.

53. Lemougna, P.N.; Wang, K.-T.; Tang, Q.; Cui, X. Synthesis and characterization of low temperature $\left(<800{ }^{\circ} \mathrm{C}\right)$ ceramics from red mud geopolymer precursor. Constr. Build. Mater. 2017, 131, 564-573. [CrossRef]

54. Ribeiro, D.V.; Labrincha, J.; Morelli, M. Effect of red mud addition on the corrosion parameters of reinforced concrete evaluated by electrochemical methods. Rev. Ibracon Estrut. Mater. 2012, 5, 451-467. [CrossRef]

55. Mukiza, E.; Zhang, L.; Liu, X.; Zhang, N. Utilization of red mud in road base and subgrade materials: A review. Resour. Conserv. Recycl. 2019, 141, 187-199. [CrossRef]

56. Renforth, P. The negative emission potential of alkaline materials. Nat. Commun. 2019, 10, 1-8. [CrossRef] [PubMed]

57. Mathisen, A.; Sørensen, H.; Melaaen, M.; Müller, G.-I. Investigation into Optimal CO2 Concentration for CO2 Capture from Aluminium Production. Energy Procedia 2013, 37, 7168-7175. [CrossRef]

58. Mahinroosta, M.; Allahverdi, A. Hazardous aluminum dross characterization and recycling strategies: A critical review. J. Environ. Manag. 2018, 223, 452-468. [CrossRef] [PubMed]

59. Hao, H.; Geng, Y.; Hang, W. GHG emissions from primary aluminum production in China: Regional disparity and policy implications. Appl. Energy 2016, 166, 264-272. [CrossRef]

60. Hartley, K.; van Santen, R.; Kirchherr, J. Policies for transitioning towards a circular economy: Expectations from the European Union (EU). Resour. Conserv. Recycl. 2020, 155, 104634. [CrossRef]

61. Aranda-Usón, A.; Portillo-Tarragona, P.; Scarpellini, S.; Llena-Macarulla, F. The progressive adoption of a circular economy by businesses for cleaner production: An approach from a regional study in Spain. J. Clean. Prod. 2020, 247, 119648. [CrossRef]

62. Falcone, P.M. Tourism-Based Circular Economy in Salento (South Italy): A SWOT-ANP Analysis. Soc. Sci. 2019, 8, 216. [CrossRef]

63. D'Adamo, I.; Falcone, P.M.; Huisingh, D.; Morone, P. A circular economy model based on biomethane: What are the opportunities for the municipality of Rome and beyond? Renew. Energy 2021, 163, 1660-1672. [CrossRef]

64. D'Adamo, I.; Falcone, P.M.; Martin, M.; Rosa, P. A Sustainable Revolution: Let's Go Sustainable to Get Our Globe Cleaner. Sustainability 2020, 12, 4387. [CrossRef]

65. Power, G.; Gräfe, M.; Klauber, C. Bauxite residue issues: I. Current management, disposal and storage practices. Hydrometallurgy 2011, 108, 33-45. [CrossRef] 
66. Liu, Y.; Naidu, R. Hidden values in bauxite residue (red mud): Recovery of metals. Waste Manag. 2014, 34, 2662-2673. [CrossRef]

67. Kinnarinen, T.; Lubieniecki, B.; Holliday, L.; Helsto, J.-J.; Häkkinen, A. Recovery of sodium from bauxite residue by pressure filtration and cake washing. Int. J. Miner. Process. 2015, 141, 20-26. [CrossRef]

68. Liu, W.; Sun, S.; Zhang, L.; Jahanshahi, S.; Yang, J. Experimental and simulative study on phase transformation in Bayer red mud soda-lime roasting system and recovery of Al, Na and Fe. Miner. Eng. 2012, 39, 213-218. [CrossRef]

69. Gelencsér, A.; Kováts, N.; Turóczi, B.; Rostási, Á.; Hoffer, A.; Imre, K.; Nyirő-Kósa, I.; Csákberényi-Malasics, D.; Tóth, Á.; Czitrovszky, A.; et al. The Red Mud Accident in Ajka (Hungary): Characterization and Potential Health Effects of Fugitive Dust. Environ. Sci. Technol. 2011, 45, 1608-1615. [CrossRef] [PubMed]

70. Rai, S.; Bahadure, S.; Chaddha, M.J.; Agnihotri, A. Disposal Practices and Utilization of Red Mud (Bauxite Residue): A Review in Indian Context and Abroad. J. Sustain. Met. 2020, 6, 1-8. [CrossRef]

71. Gomes, H.I.; Mayes, W.; Rogerson, M.; Stewart, D.; Burke, I.T. Alkaline residues and the environment: A review of impacts, management practices and opportunities. J. Clean. Prod. 2016, 112, 3571-3582. [CrossRef]

72. Souza, M.T.; Simão, L.; Montedo, O.R.K.; Pereira, F.R.; de Oliveira, A.P.N. Aluminum anodizing waste and its uses: An overview of potential applications and market opportunities. Waste Manag. 2019, 84, 286-301. [CrossRef] [PubMed]

73. Shinomiya, L.D.; Alves, J.O.; de Oliveira Gomes, J. Planejamento de Cenários para uso de Resíduos Industriais: Aplicação para Lama Vermelha. In Proceedings of the Anais do Congresso Anual da ABM.; Editora Blucher: São José dos Campos, Brazil, 2017.

74. Lyu, F.; Hu, Y.; Wang, L.; Sun, W. Dealkalization processes of bauxite residue: A comprehensive review. J. Hazard. Mater. 2021, 403, 123671. [CrossRef]

75. Lima, M.S.S.; Thives, L.P.; Haritonovs, V.; Bajars, K. Red mud application in construction industry: Review of benefits and possibilities. IOP Conf. Ser. Mater. Sci. Eng. 2017, 251, 12033. [CrossRef]

76. Filho, E.B.S.; Alves, M.; Da Motta, M.; Sobrinho, M.A.D.M. Lama vermelha da indústria de beneficiamento de alumina: Produção, características, disposição e aplicações alternativas. Matéria 2007, 12, 322-338. [CrossRef]

77. Sutar, H.; Mishra, S.C.; Sahoo, S.K.; Chakraverty, A.P.; Maharana, H.S. Progress of Red Mud Utilization: An Overview. Am. Chem. Sci. J. 2014, 4, 255-279. [CrossRef]

78. International Aluminium Institute. Opportunities for Use of Bauxite Residue in Supplementary Cementitious Materials, 2020. Available online: https: / / www.google.com.hk/url?sa=t\&rct=j\&q=\&esrc=s\&source=web\&cd=\&cad=rja\&uact=8\&ved=2ahUKEwjNz Cf4KD0AhVRyIsBHTlwDSoQFnoECAwQAQ\&url=https:/ / reactivproject.eu/wp-content/uploads/2021/01/technology_ roadmap_-_br_use_in_cement_2020.pdf\&usg=AOvVaw2tvwiwOcTVigTnL-pC8IVe (accessed on 29 September 2020).

79. Hairi, S.N.M.; Jameson, G.N.L.; Rogers, J.J.; MacKenzie, K.J.D. Synthesis and properties of inorganic polymers (geopolymers) derived from Bayer process residue (red mud) and bauxite. J. Mater. Sci. 2015, 50, 7713-7724. [CrossRef]

80. Hu, Y.; Liang, S.; Yang, J.; Chen, Y.; Ye, N.; Ke, Y.; Tao, S.; Xiao, K.; Hu, J.; Hou, H.; et al. Role of Fe species in geopolymer synthesized from alkali-thermal pretreated Fe-rich Bayer red mud. Constr. Build. Mater. 2019, 200, 398-407. [CrossRef]

81. Krivenko, P.; Kovalchuk, O.; Pasko, A.; Croymans, T.; Hult, M.; Lutter, G.; Vandevenne, N.; Schreurs, S.; Schroeyers, W. Development of alkali activated cements and concrete mixture design with high volumes of red mud. Constr. Build. Mater. 2017, 151, 819-826. [CrossRef]

82. Bădănoiu, A.I.; Al-Saadi, T.H.A.; Voicu, G. Synthesis and properties of new materials produced by alkaline activation of glass cullet and red mud. Int. J. Miner. Process. 2015, 135, 1-10. [CrossRef]

83. Zhang, Y.; Xu, R.; Tang, H.; Wang, L.; Sun, W. A review on approaches for hazardous organics removal from Bayer liquors. J. Hazard. Mater. 2020, 397, 122772. [CrossRef] [PubMed]

84. Do, T.; Kang, G.-O.; Kim, Y.-S. Development of a new cementless binder for controlled low strength material (CLSM) using entirely by-products. Constr. Build. Mater. 2019, 206, 576-589. [CrossRef]

85. Cardenia, C.; Balomenos, E.; Panias, D. Iron Recovery from Bauxite Residue Through Reductive Roasting and Wet Magnetic Separation. J. Sustain. Met. 2018, 5, 9-19. [CrossRef]

86. Koshy, N.; Dondrob, K.; Hu, L.; Wen, Q.; Meegoda, J.N. Synthesis and characterization of geopolymers derived from coal gangue, fly ash and red mud. Constr. Build. Mater. 2019, 206, 287-296. [CrossRef]

87. Pérez-Villarejo, L.; Iglesias, F.A.C.; Martínez, S.M.; Artiaga, R.; Pascual-Cosp, J. Manufacturing new ceramic materials from clay and red mud derived from the aluminium industry. Constr. Build. Mater. 2012, 35, 656-665. [CrossRef]

88. Borra, C.R.; Pontikes, Y.; Binnemans, K.; Van Gerven, T. Leaching of rare earths from bauxite residue (red mud). Miner. Eng. 2015, 76, 20-27. [CrossRef]

89. Agrawal, S.; Dhawan, N. Investigation of mechanical and thermal activation on metal extraction from red mud. Sustain. Mater. Technol. 2021, 27, e00246. [CrossRef]

90. Valeev, D.; Zinoveev, D.; Kondratiev, A.; Lubyanoi, D.; Pankratov, D. Reductive Smelting of Neutralized Red Mud for Iron Recovery and Produced Pig Iron for Heat-Resistant Castings. Metals 2019, 10, 32. [CrossRef]

91. Shoppert, A.A.; Loginova, I.V.; Rogozhnikov, D.A.; Karimov, K.A.; Chaikin, L.I. Increased As Adsorption on MaghemiteContaining Red Mud Prepared by the Alkali Fusion-Leaching Method. Minerals 2019, 9, 60. [CrossRef]

92. Ribeiro, D.; Labrincha, J.; Morelli, M.R. Potential use of natural red mud as pozzolan for Portland cement. Mater. Res. 2011, 14, 60-66. [CrossRef]

93. Mercury, J.M.R.; Cabral, A.; Paiva, A.E.M.; Angélica, R.S.; Neves, R.F.; Scheller, T. Thermal behavior and evolution of the mineral phases of Brazilian red mud. J. Therm. Anal. Calorim. 2010, 104, 635-643. [CrossRef] 
94. Romano, R.C.D.O.; Bernardo, H.M.; Maciel, M.H.; Pileggi, R.G.; Cincotto, M.A. Using isothermal calorimetry, X-ray diffraction, thermogravimetry and FTIR to monitor the hydration reaction of Portland cements associated with red mud as a supplementary material. J. Therm. Anal. Calorim. 2019, 137, 1877-1890. [CrossRef]

95. Alekseev, K.; Mymrin, V.; Avanci, M.A.; Klitzke, W.; Magalhaes, W.; Silva, P.R.; Catai, R.E.; Silva, D.A.; Ferraz, F.A. Environmentally clean construction materials from hazardous bauxite waste red mud and spent foundry sand. Constr. Build. Mater. 2019, 229, 116860. [CrossRef]

96. Manfroi, E.P.; Cheriaf, M.; Rocha, J.C. Microstructure, mineralogy and environmental evaluation of cementitious composites produced with red mud waste. Constr. Build. Mater. 2014, 67, 29-36. [CrossRef]

97. Babisk, M.P.; Amaral, L.F.; Ribeiro, L.D.S.; Vieira, C.M.F.; Prado, U.S.D.; Gadioli, M.C.B.; Oliveira, M.S.; da Luz, F.S.; Monteiro, S.N.; Filho, F.D.C.G. Evaluation and application of sintered red mud and its incorporated clay ceramics as materials for building construction. J. Mater. Res. Technol. 2020, 9, 2186-2195. [CrossRef]

98. Scribot, C.; Maherzi, W.; Benzerzour, M.; Mamindy-Pajany, Y.; Abriak, N.-E. A laboratory-scale experimental investigation on the reuse of a modified red mud in ceramic materials production. Constr. Build. Mater. 2018, 163, 21-31. [CrossRef]

99. Geng, C.; Liu, J.; Wu, S.; Jia, Y.; Du, B.; Yu, S. Novel method for comprehensive utilization of MSWI fly ash through co-reduction with red mud to prepare crude alloy and cleaned slag. J. Hazard. Mater. 2020, 384, 121315. [CrossRef]

100. Díaz, Y.C.; Berriel, S.S.; Heierli, U.; Favier, A.; Machado, I.R.S.; Scrivener, K.L.; Hernández, J.F.M.; Habert, G. Limestone calcined clay cement as a low-carbon solution to meet expanding cement demand in emerging economies. Dev. Eng. 2017, 2, 82-91. [CrossRef]

101. Scrivener, K.L.; John, V.M.; Gartner, E.M. Eco-efficient cements: Potential economically viable solutions for a low-CO $\mathrm{C}_{2}$ cementbased materials industry. Cem. Concr. Res. 2018, 114, 2-26. [CrossRef]

102. Teixeira, A.H.C.; Junior, P.R.R.S.; Silva, T.H.; Barreto, R.R.; Bezerra, A.C.D.S. Low-Carbon Concrete Based on Binary Biomass Ash-Silica Fume Binder to Produce Eco-Friendly Paving Blocks. Materials 2020, 13, 1534. [CrossRef] [PubMed]

103. Bezerra, A.C.D.S.; Saraiva, S.L.C.; Lara, L.F.D.S.; De Castro, L.W.A.; Gomes, R.C.; Rodrigues, C.D.S.; Ferreira, M.C.N.F.; Aguilar, M.T.P. Effect of partial replacement with thermally processed sugar cane bagasse on the properties of mortars. Matéria 2017, 22. [CrossRef]

104. Tang, W.; Wang, Z.; Donne, S.; Forghani, M.; Liu, Y. Influence of red mud on mechanical and durability performance of self-compacting concrete. J. Hazard. Mater. 2019, 379, 120802. [CrossRef] [PubMed]

105. Zhang, J.; Li, S.; Li, Z.; Liu, C.; Gao, Y.; Qi, Y. Properties of red mud blended with magnesium phosphate cement paste: Feasibility of grouting material preparation. Constr. Build. Mater. 2020, 260, 119704. [CrossRef]

106. Li, X.; Zhang, Q.; Mao, S. Investigation of the bond strength and microstructure of the interfacial transition zone between cement paste and aggregate modified by Bayer red mud. J. Hazard. Mater. 2021, 403, 123482. [CrossRef]

107. Saravanan, B.; Vijayan, D. Status review on experimental investigation on replacement of red-mud in cementitious concrete. Mater. Today Proc. 2020, 33, 593-598. [CrossRef]

108. Venkatesh, C.; Nerella, R.; Chand, M.S.R. Comparison of mechanical and durability properties of treated and untreated red mud concrete. In Proceedings of the Materials Today: Proceedings; Elsevier BV: Amsterdam, The Netherland, 2019; Volume 27, pp. 284-287.

109. Arina, D.; Bendere, R. Waste as energy source in EU action plan for the circular economy. Environ. Res. Eng. Manag. 2018, 74, 43-49. [CrossRef]

110. Nikbin, I.; Aliaghazadeh, M.; Charkhtab, S.; Fathollahpour, A. Environmental impacts and mechanical properties of lightweight concrete containing bauxite residue (red mud). J. Clean. Prod. 2018, 172, 2683-2694. [CrossRef]

111. Yao, Y.; Li, Y.; Liu, X.; Jiang, S.; Feng, C.; Rafanan, E. Characterization on a cementitious material composed of red mud and coal industry byproducts. Constr. Build. Mater. 2013,47, 496-501. [CrossRef]

112. Kumar, A.; Kumar, S. Development of paving blocks from synergistic use of red mud and fly ash using geopolymerization. Constr. Build. Mater. 2013, 38, 865-871. [CrossRef]

113. Bonet-Martínez, E.; Pérez-Villarejo, L.; Eliche-Quesada, D.; Carrasco-Hurtado, B.; Bueno, S.; Castro-Galiano, E. Inorganic polymers synthesized using biomass ashes-red mud as precursors based on clay-kaolinite system. Mater. Lett. 2018, 225, 161-166. [CrossRef]

114. Liu, S.; Li, Z.; Li, Y.; Cao, W. Strength properties of Bayer red mud stabilized by lime-fly ash using orthogonal experiments. Constr. Build. Mater. 2018, 166, 554-563. [CrossRef]

115. Liu, J.; Li, X.; Lu, Y.; Bai, X. Effects of $\mathrm{Na} / \mathrm{Al}$ ratio on mechanical properties and microstructure of red mud-coal metakaolin geopolymer. Constr. Build. Mater. 2020, 263, 120653. [CrossRef]

116. Li, Z.; Zhang, J.; Li, S.; Gao, Y.; Liu, C.; Qi, Y. Effect of different gypsums on the workability and mechanical properties of red mud-slag based grouting materials. J. Clean. Prod. 2020, 245, 118759. [CrossRef]

117. Ke, X.; Bernal, S.A.; Ye, N.; Provis, J.L.; Yang, J. One-Part Geopolymers Based on Thermally Treated Red Mud/NaOH Blends. J. Am. Ceram. Soc. 2015, 98, 5-11. [CrossRef]

118. Zhang, G.; He, J.; Gambrell, R.P. Synthesis, Characterization, and Mechanical Properties of Red Mud-Based Geopolymers. Transp. Res. Rec. J. Transp. Res. Board 2010, 2167, 1-9. [CrossRef]

119. Zhao, Y.; Liang, N.; Chen, H.; Li, Y. Preparation and properties of sintering red mud unburned road brick using orthogonal experiments. Constr. Build. Mater. 2020, 238, 117739. [CrossRef] 
120. Chen, R.; Cai, G.; Dong, X.; Mi, D.; Puppala, A.J.; Duan, W. Mechanical properties and micro-mechanism of loess roadbed filling using by-product red mud as a partial alternative. Constr. Build. Mater. 2019, 216, 188-201. [CrossRef]

121. Mu, M.; Gao, X.; Guo, T.; Hu, X. Experimental Study of Goaf Filling Materials Based on Red Mud. IOP Conf. Ser. Mater. Sci. Eng. 2018, 301, 012055. [CrossRef]

122. Evans, K. The History, Challenges, and New Developments in the Management and Use of Bauxite Residue. J. Sustain. Met. 2016, 2, 316-331. [CrossRef]

123. Wang, L.; Sun, N.; Tang, H.; Sun, W. A Review on Comprehensive Utilization of Red Mud and Prospect Analysis. Minerals 2019, 9, 362. [CrossRef]

124. Vangelatos, I.; Angelopoulos, G.; Boufounos, D. Utilization of ferroalumina as raw material in the production of Ordinary Portland Cement. J. Hazard. Mater. 2009, 168, 473-478. [CrossRef]

125. Liu, X.; Zhang, N. Utilization of red mud in cement production: A review. Waste Manag. Res. 2011, 29, 1053-1063. [CrossRef]

126. Singh, M.; Upadhayay, S.; Prasad, P. Preparation of iron rich cements using red mud. Cem. Concr. Res. 1997, 27, 1037-1046. [CrossRef]

127. Tsakiridis, P.; Agatzini-Leonardou, S.; Oustadakis, P. Red mud addition in the raw meal for the production of Portland cement clinker. J. Hazard. Mater. 2004, 116, 103-110. [CrossRef] [PubMed]

128. Wang, W.; Wang, X.; Zhu, J.; Wang, P.; Ma, C. Experimental Investigation and Modeling of Sulfoaluminate Cement Preparation Using Desulfurization Gypsum and Red Mud. Ind. Eng. Chem. Res. 2013, 52, 1261-1266. [CrossRef]

129. Canbek, O.; Shakouri, S.; Erdoğan, S.T. Laboratory production of calcium sulfoaluminate cements with high industrial waste content. Cem. Concr. Compos. 2020, 106, 103475. [CrossRef]

130. Wang, Y.; Zhang, T.-A.; Lyu, G.; Guo, F.; Zhang, W.; Zhang, Y. Recovery of alkali and alumina from bauxite residue (red mud) and complete reuse of the treated residue. J. Clean. Prod. 2018, 188, 456-465. [CrossRef]

131. Wang, Y.; Zhang, T.-A.; Zhang, Y.; Lv, G.; Zhang, W. Transformation and Characterization of Cement Clinker Prepared from New Structured Red Mud by Sintering. JOM 2019, 71, 2505-2512. [CrossRef]

132. Pera, J.; Boumaza, R.; Ambroise, J. Development of a pozzolanic pigment from red mud. Cem. Concr. Res. 1997, $27,1513-1522$. [CrossRef]

133. Dow, C.; Glasser, F.P. Alkali releases from crushed minerals and thermally activated constituents of metakaolin. Adv. Cem. Res. 2003, 15, 137-143. [CrossRef]

134. Romano, R.C.O.; Bernardo, H.M.; Maciel, M.H.; Pileggi, R.G.; Cincotto, M.A. Hydration of Portland cement with red mud as mineral addition. J. Therm. Anal. Calorim. 2018, 131, 2477-2490. [CrossRef]

135. Dodoo-Arhin, D.; Nuamah, R.A.; Agyei-Tuffour, B.; Obada, D.O.; Yaya, A. Awaso bauxite red mud-cement based composites: Characterisation for pavement applications. Case Stud. Constr. Mater. 2017, 7, 45-55. [CrossRef]

136. Wang, X.; Zhang, L.; Luo, Z.; Yang, J. Effect of Red Mud on Properties and Mineral Composition of Portland Cement for Road, Jianzhu Cailiao Xuebao. J. Build. Mater. 2017, 20, 774-779. [CrossRef]

137. Tang, W.; Wang, Z.; Liu, Y.; Cui, H. Influence of red mud on fresh and hardened properties of self-compacting concrete. Constr. Build. Mater. 2018, 178, 288-300. [CrossRef]

138. Liu, Y.; Qin, Z.; Chen, B. Experimental research on magnesium phosphate cements modified by red mud. Constr. Build. Mater. 2020, 231, 117131. [CrossRef]

139. Bayat, A.; Hassani, A.; Azami, O. Thermo-mechanical properties of alkali-activated slag-Red mud concrete. Road Mater. Pavement Des. 2018, 21, 411-433. [CrossRef]

140. Li, X.; Zhang, Q.; Mao, S.; Li, L.; Wang, J. Study on the Preparation and Fracture Behavior of Red Mud-Yellow Phosphorus Slag-Based Concrete. Adv. Mater. Sci. Eng. 2019, 2019, 1-15. [CrossRef]

141. Raj, R.R.; Brijitta, J.; Ramachandran, D.; Pillai, E.B.P. Microstructure Evolution in Ordinary Portland Cement-Metakaolin-Red Mud-Based Ternary Blended Cement. J. Inst. Eng. Ser. A 2019, 100, 707-718. [CrossRef]

142. Ghalehnovi, M.; Roshan, N.; Hakak, E.; Shamsabadi, E.A.; de Brito, J. Effect of red mud (bauxite residue) as cement replacement on the properties of self-compacting concrete incorporating various fillers. J. Clean. Prod. 2019, 240, 118213. [CrossRef]

143. Ghalehnovi, M.; Shamsabadi, E.A.; Khodabakhshian, A.; Sourmeh, F.; de Brito, J. Self-compacting architectural concrete production using red mud. Constr. Build. Mater. 2019, 226, 418-427. [CrossRef]

144. Venkatesh, C.; Chand, M.; Nerella, R. A State of the Art on Red Mud as a Substitutional Cementitious Material. Ann. Chim. Sci. Matériaux 2019, 43, 99-103. [CrossRef]

145. Abdel-Raheem, M.; Santana, L.M.G.; Cordava, M.A.P.; Martínez, B.O. Uses of Red Mud as a Construction Material. In AEI 2017; American Society of Civil Engineers (ASCE): Reston, VA, USA, 2017.

146. Yuan, B.; Yuan, S.; Straub, C.; Chen, W. Activation of Binary Binder Containing Fly Ash and Portland Cement Using Red Mud as Alkali Source and Its Application in Controlled Low-Strength Materials. J. Mater. Civ. Eng. 2020, 32, 04019356. [CrossRef]

147. Do, T.; Kim, Y.-S. Engineering properties of controlled low strength material (CLSM) incorporating red mud. Int. J. Geo-Eng. 2016, 7, 1-17. [CrossRef]

148. Ke, X.; Ye, N.; Bernal, S.; Provis, J. Preparation of one-part geopolymer from thermal-alkali activated red mud. In Proceedings of the 2nd International Conference on Advances in Chemically Activated Materials, Changsha, China, 1-3 June 2014.

149. Li, Y.; Min, X.; Ke, Y.; Liu, D.; Tang, C. Preparation of red mud-based geopolymer materials from MSWI fly ash and red mud by mechanical activation. Waste Manag. 2019, 83, 202-208. [CrossRef] 
150. Yang, Z.; Mocadlo, R.; Zhao, M.; Sisson, R.D.; Tao, M.; Liang, J. Preparation of a geopolymer from red mud slurry and class F fly ash and its behavior at elevated temperatures. Constr. Build. Mater. 2019, 221, 308-317. [CrossRef]

151. Hyeok-Jung, K.; Kang, S.-P.; Choe, G.-C. Effect of Red Mud Content on Strength and Efflorescence in Pavement using AlkaliActivated Slag Cement. Int. J. Concr. Struct. Mater. 2018, 12, 18. [CrossRef]

152. Zhang, M.; Zhao, M.; Zhang, G.; Mann, D.; Lumsden, K.; Tao, M. Durability of red mud-fly ash based geopolymer and leaching behavior of heavy metals in sulfuric acid solutions and deionized water. Constr. Build. Mater. 2016, 124, 373-382. [CrossRef]

153. Zhang, M.; El-Korchi, T.; Zhang, G.; Liang, J.; Tao, M. Synthesis factors affecting mechanical properties, microstructure, and chemical composition of red mud-fly ash based geopolymers. Fuel 2014, 134, 315-325. [CrossRef]

154. Choo, H.; Lim, S.; Lee, W.; Lee, C. Compressive strength of one-part alkali activated fly ash using red mud as alkali supplier. Constr. Build. Mater. 2016, 125, 21-28. [CrossRef]

155. Ye, N.; Yang, J.; Ke, X.; Zhu, J.; Li, Y.; Xiang, C.; Wang, H.; Li, L.; Xiao, B. Synthesis and Characterization of Geopolymer from Bayer Red Mud with Thermal Pretreatment. J. Am. Ceram. Soc. 2014, 97, 1652-1660. [CrossRef]

156. Kaya, K.; Soyer-Uzun, S. Evolution of structural characteristics and compressive strength in red mud-metakaolin based geopolymer systems. Ceram. Int. 2016, 42, 7406-7413. [CrossRef] 